\title{
INFRASTRUCTURE PROJECTS'ASSESSMENT THROUGH SDG TARGETS: TOWARDS a COMPREHENSIVE FRAMEWORK
}

\author{
Paul Mansell ${ }^{1,2 *}$, Deney Van Rooyen ${ }^{3}$, Simon Philbin $^{2}$, and Luca Sabini ${ }^{4}$
}

\begin{abstract}
The achievement of the United Nations' Sustainable Development Goals (SDGs) is of paramount importance "for the peace and prosperity for people and the planet, now and in the future" (United Nations, 2015; Økland, 2015). Important changes are needed in order to achieve these goals, and infrastructure projects (IP) are critical to facilitate these changes at local and global levels, across health, energy, education, transport, communication and other critical infrastructure needs. However, a gap exists in understanding how SDGs are applied below the global-national levels. In order to increase global and local impact of infrastructure investments, an improved understanding is needed at organisational and infrastructure project levels. In this context, the purpose of this research study is firstly to build on a comprehensive literature review to investigate the existing UN SDG targets in relation to IP, and secondly, to lay a foundation for a comprehensive framework to structure research systematically in this field. This approach can help further our understanding of the topic, thereby providing an important contribution for regulators, policymakers, academia and practitioners on how to align IP to SDGs objectives. This will deliver increased value from infrastructure investments and enable the project management community to generate local impact on global issues, for 'people and the planet, now and in the future'.
\end{abstract}

\section{Keywords}

Sustainable Development Goals (SDGs), Sustainability, Sustainable Development, Project Success, Infrastructure project, Research framework

\footnotetext{
${ }^{1}$ Bartlett School of Sustainable Construction, London, United Kingdom

${ }^{2}$ London South Bank University, Engineering Department, Nathu Puri Institute, London, United Kingdom

${ }^{3}$ University of Cape Town, Cape Town, South Africa

${ }^{4}$ Hertfordshire University Business School, Hatfield, United Kingdom
} 


\section{INTRODUCTION}

The defining research by Morris (2017) into what the project management profession should be doing about climate change and other grand challenges, as well as by many others (Sachs et al., 2016; Seinfeld and Pandis, 2016; United Nations, 2018), suggests that the planet is in crisis and we need radical change. Morris (2017), concentrating on project management, and Sachs et al. (2016), focusing on socio-economics, have shown that never before have we had such confidence in the evidence that demonstrates how many species are threatened and our ecosystem 'faces massive change and collapse unless action is taken immediately' (Morris, 2017). The urgency of finding solutions to these challenges is highlighted by the United Nations (UN) Intergovernmental Panel on Climate Change, which released their most damning report on eighth October 2018 (United Nations, 2015,2018). The report drew on 6000 research papers. The evidence of global warming exceeding $2{ }^{\circ} \mathrm{C}$ above pre-industrial levels by the end of the century is overwhelming and indicates 'impending catastrophe' - climate change is an existential threat to the human race. Whilst there have been some significant advances since the Rio Summit (1992 and +20 in 2012) and the 2005 Kyoto Protocol (2005), such as the transformational technologies for battery-powered cars and renewable energy, even a rise of $1.5^{\circ} \mathrm{C}$ now appears to be inevitable (United Nations, 2015,2018; Sachs et al., 2016). Alongside the 'climate emergency', the widening gap between rich and poor, which is at its highest point in a decade, and growing social inequalities are fuelling social tensions and mass migration (United Nations, 2015,2018).

The response of the international community to the grand challenge of sustainable development was codified in the '2030 Agenda for Sustainable Development' that was adopted by the 193 Member States of the United Nations (2015) at the UN Sustainable Development Summit in September 2015 (United Nations, 2015; Økland, 2015). The UN General Assembly outlined seventeen Sustainable Development Goals (SDGs), as shown in Figure 1, that are intended to provide a universal call to action to end poverty, protect the planet and ensure that all people enjoy peace and prosperity.

Five years into the global commitment to deliver meaningful SDG action, it is evident that we are falling behind on our local and global ambitions (Organisation for Economic Co-Operation and Development (OECD), 2019; United Nations, 2015, 2019). This is relevant for project managers because much of tomorrow's development will be delivered through projects (and by project management professionals), across all sectors, but especially infrastructure. For example, the IPCC's October 2018 Report identifies that "directing
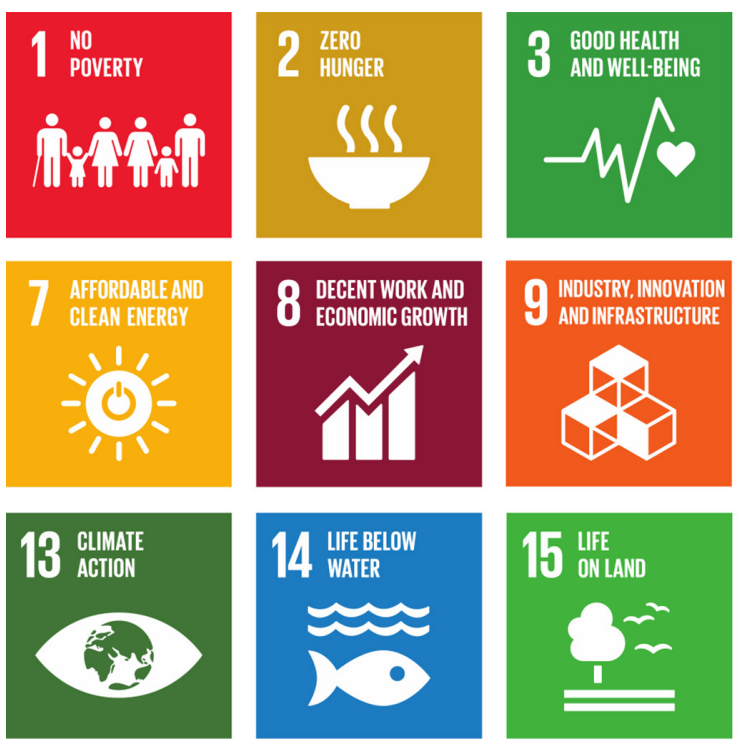
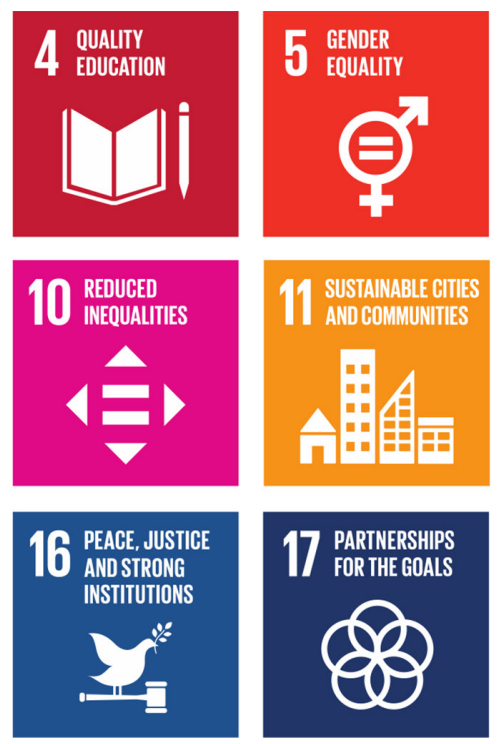
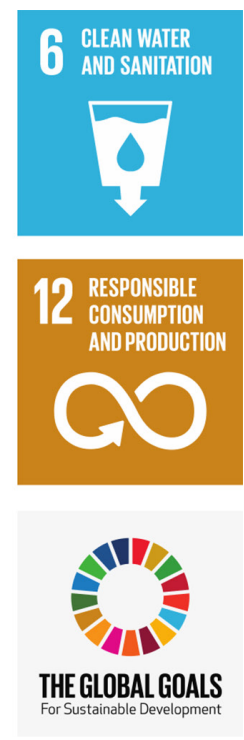

Figure 1 The Global Goals. United Nations (2018). 
finance towards investment in infrastructure for mitigation and adaptation" is key to meeting SDG targets. Another indication of the importance of IP is shown by the estimated USD \$94 trillion (Global Infrastructure Outlook, 2019) of investment in IP that is required globally between 2018 and 2040. This represents a significant opportunity to stimulate economic prosperity, reduce poverty and raise standards in health, education and gender equality. Equally, done badly, the evidence suggests (Silvius et al., 2012; Thacker and Hall, 2018; Thacker et al., 2019) that economic benefits from projects' impacts could be outweighed by the negative impact on the environment and society.

Given the preeminent importance that large (and mega-) projects have in pursuing high level societal changes (and potentially contributing massively to SDG achievement), this research study explores the gap in the literature by focusing on the measurement of IP through SDG targets. The study asks an overarching question: What are the opportunities for research into the assessment of Infrastructure Projects through SDG targets? In exploring this question, the study develops around three research questions, that can be used as a guide for broader research: (1) How extensive (broad and deep) has the research into SDG-IP been to-date?; (2) What issues and sub-issues were identified that may inform a future thematic framework to support more systematic research in the field?; and (3) How could such a framework be used to provide guidance to a range of stakeholders (including regulators, policymakers, academia, investors and infrastructure practitioners) on how to align IP and their impacts to the SDGs?

This article is structured as follows: In the first part we explore the background information where concepts of grand challenges, sustainability (and sustainable development), infrastructure projects, and project success in relation to the SDGs have been examined. This is followed by a description of the methodology employed for the systematic literature review. Subsequently, we delineate preliminary results from the systematic literature review. In the concluding part we develop a research framework with critical SDG-IP issues that can be used for further research to support the project level implementation of the 2030 SDG targets.

\section{THEORETICAL BACKGROUND}

\section{Grand Challenges and SDGs}

Grand Challenges is a term used, predominantly by the academic community, to qualify and structure responses to so called 'wicked problems' (Head and Alford, 2015) of immense magnitude and impact. 'Grand Challenges' capture ideas that are equally relevant to academics as well as practitioners. They are also, by definition, both ambitious ("capture the peoples' imagination") and achievable ("solve ... problems") (Executive Office of the President, Office of Science and Technology Policy, 1989). Additionally, the definition identifies the need for impact and the measurement thereof to demonstrate meaningful progress. The definition of Grand Challenges has evolved since Mertz (2005) focus on the engineering communities, to a broader group of stakeholders that includes policy shapers, funders, and delivery-to-operations project teams (Omenn, 2006). Consequently, project management professionals have the opportunity to take a leading role in this, especially in providing tangible action that can be implemented by practitioners to effect improved performance against the SDG targets.

More recent research into Grand Challenges (Sakhrani et al., 2016) has identified five characteristics that are helpful in this paper's SDG-IP analysis: Grand Challenges are (a) articulated by stakeholders, (b) specific, (c) ambitious yet feasible, (d) framed in a manner that suggests the use of specific methods or disciplines, and (e) have the potential for broad impact. These characteristics provide a useful reference point for developing a conceptual framework to deepen the research into how the project management community can define, design and measure IP contributions towards the SDGs. In effect, the five characteristics of the Grand Challenges provide the 'lens' to identify what links SDGs to IP.

\section{Sustainability and Sustainable Develop- ment in Relation to SDGs}

Sustainability can be a challenging word. Indeed, fifteen years ago there were up to sixty definitions of sustainability (Hartshorn et al., 2005) with little 
convergence of how the theory of sustainability could be given meaning in practice. There are those (Sverdrup and Rosen, 1998; Zuofa and Ochieng, 2016) who suggest that sustainability is essentially the long-term harnessing of an ecosystem to maximise the outcomes whilst ensuring the extraction of the input of resources from the ecosystem do not negatively impact its long-term viability. Alternatively, there are others (Costanza and Patten, 1995) who define sustainability simply as a measure of whether a system can ultimately continue or is self-consuming. Holling (2001) broadened the sustainability systems' definition to include 'development': "Sustainable development ... refers to the goal of fostering adaptive capabilities and creating opportunities". It can thus be shown that 'sustainability' has become mired in valueladen language, often vague in concept (Ciegis et al., 2009; Emas, 2015; Mebratu, 1998), that can cause diffusion of interpretation and confusion in practice (Ainger and Fenner, 2014; Fenner et al., 2006; Moore et al., 2017). These examples explain why the definition remains nebulous and why a practical definition has greater utility (Glavic and Lukman, 2007) for project managers.

For the purposes of this paper, the definition of sustainability builds on the broader definition of sustainable development as "development that meets the needs of the present without compromising the ability of future generations to meet their own needs" (Brundtland, 1987). Over the past 50 years, the phraseology and understanding of 'sustainable development' (Sachs et al., 2016) has become an increasingly central theme of nation states and their citizens. Today, the Planetary Boundaries (Rockström et al., 2009; Steffen et al., 2015) provide a global litmus test for how we are doing. The concept of nine planetary boundaries within which humanity can continue to develop and thrive for generations to come was developed in 2009 by environmental scientists from the Stockholm Resilience Centre. The most significant global response to the Planetary Boundary challenge was in 2015, when all governments ratified the UN's seventeen Sustainable Development Goals (United Nations, 2015; Økland, 2015) to be achieved by 2030. To this end, 169 targets linked to 247 (231 without duplicates) indicators were agreed in 2017. This represented a major step-change in the implementation of the sustainability agenda and effective responses to the Planetary Boundary challenge. Although the SDGs build on the earlier Millennium Development Goals (MDGs) (United Nations, 2015, 2000), by focusing on similar issues, the SDGs differ from the MDGs in that they are for all countries in the world to implement developed and developing nations alike. Also, unlike the MDGs, the SDGs are focused on monitoring, evaluation and accountability - across society, not just at national level. Therefore, it is critical that the link is made from 'bottom-to-top', meaning that impacts can be measured at project level and this can be benchmarked against the national and global targets and indicators. We argue that a gap exists - IP are not included in the SDGs' measurement, and the evidence (Martens and Carvalho, 2017 and Martens and Carvalho, 2016b) illustrates that the golden thread from project level measurement to global-national level, is missing. This echoes research highlighting a gap between theory and practice for incorporating sustainability measurement in project management (Økland, 2015).

\section{Sustainable IPs and Project Success in Relation to SDGs}

Most of society's developments in recent times can be connected to IP (Thacker and Hall, 2018; Thacker et al., 2019) and the UN recognise that the development of infrastructure represents a massive opportunity to stimulate economic prosperity, reduce poverty and raise standards in health, education and gender equality (United Nations Intergovernmental Science-Policy Platform on Biodiversity and Ecosystem Services, 2019).

It is apparent that ameliorating many of the risks associated with grand challenges, such as climate change, can only be achieved through investment in appropriate and resilient infrastructure and engineering (Organisation for Economic Co-Operation and Development (OECD), 2019). For example, greenhouse gas emissions cannot be sufficiently reduced without new forms of energy infrastructure or less polluting transport networks; and water security requires investment in new and more resilient forms of water infrastructure (Organisation for Economic Co-Operation and 
SDG targets?) and the earlier exploration of the key thematic areas, the following systems map at Figure 2 was developed to guide the choice of methodology, based on the six core areas that are all linked as a systems-of-systems map. This demonstrates their interconnections and the basis for the chosen research approach.

\section{METHODOLOGY}

In order to meet our research objectives, we decided to conduct a systematic literature review (SLR) focused on the leading journals that publish articles across the three thematics of business policy, sustainability and project management. A literature review can broadly be described as a systematic way of collecting and synthesising previous research (Baumeister and Leary, 1997; Tranfield et al., 2003). We selected an approach that conformed to established SLR protocols that have been mostly based on the rules and standards proposed by Liberati et al. (2009). This was complemented by a Level 2 Analysis that adopted a semi-systematic review process, advocated by Wong (2013), that evaluated the top 13 articles that had the highest prevalence of keywords within the selected dataset, and this supported the derived nodal map of key thematics that provide future research opportunities. These approaches are shown diagrammatically in Figure 3.

Withanaimtoensuresufficientlycomprehensive coverage across the three thematics, we focused our research on project management journals (International Journal of Project Management, and Project Management Journal), sustainability journals (Journal of Cleaner Production, and Sustainability); and policy journals (Journal of Environmental Management, Business Strategy and the Environment, Environmental Science and Policy, Research Policy, and Global Environmental Change). Combined, these journals publish the representative coverage of academic research across the three thematics of project management, sustainability and business policy.

In order to assemble the dataset, we used Scopus as the search engine, identifying articles by source types (peer-reviewed articles within the 


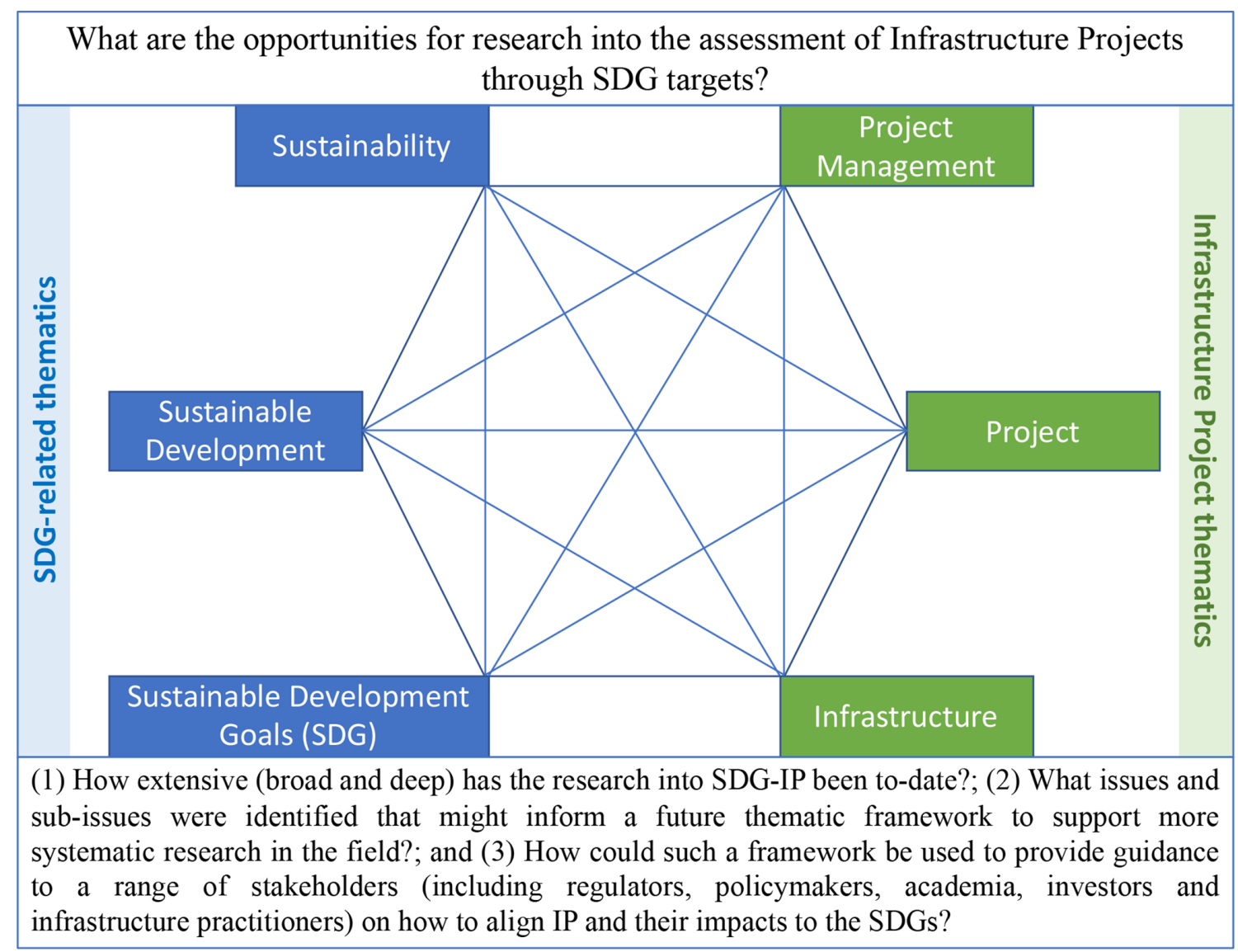

Figure 2 Systems map showing the key thematic areas related to the research question.

\begin{tabular}{|c|c|c|c|c|}
\hline & $\begin{array}{l}\text { Policy Management } \\
\text { Journals (3) }\end{array}$ & $\begin{array}{l}\text { Environment } \\
\text { Journals (5) }\end{array}$ & $\begin{array}{l}\text { Project Management } \\
\text { Journals (2) }\end{array}$ & \\
\hline $\begin{array}{l}\text { Level } 1 \text { SLR Quant } \\
\text { Analysis based on the }\end{array}$ & 204 & 1426 & 21 & $\begin{array}{l}\text { a. Articles containing } \\
\text { Keywords }\end{array}$ \\
\hline $\begin{array}{l}\text { rules and standards } \\
\text { proposed by Liberati et } \\
\text { al., (2009), to identify } \\
\text { suitable journal articles }\end{array}$ & & 69 & & $\begin{array}{l}\text { b. Articles based on } \\
\text { combinations of } \\
\text { Keywords }\end{array}$ \\
\hline $\begin{array}{l}\text { that match the keyword } \\
\text { areas of interest. }\end{array}$ & & & & $\begin{array}{l}\text { c. As for ' } b \text { ' but highly } \\
\text { relevant }\end{array}$ \\
\hline \multicolumn{2}{|c|}{$\begin{array}{l}\text { Level } 2 \text { SLR Qual Analysis of the } 14 \\
\text { top SDG-IP articles based on their } \\
\text { keyword occurrence adopting semi- } \\
\text { systematic review process, advocated } \\
\text { by Wong et al.,(2013). }\end{array}$} & & \multicolumn{2}{|c|}{$\begin{array}{l}\text { The Level } 2 \text { Analysis involved the review } \\
\text { of the top } 14 \text { articles to identify issues } \\
\text { and sub-issues that provide insights into } \\
\text { how a nodal thematics structure might } \\
\text { be evolved for further research }\end{array}$} \\
\hline
\end{tabular}

Figure 3 The 'hopper' approach to SLR Level 1 and 2 Analysis. 
Table 1 Items containing combinations of keywords

\begin{tabular}{|l|c|c|c|}
\hline & No. of items & & \multicolumn{2}{l|}{$\begin{array}{l}\text { Index } \\
\text { Key } \\
\text { Words }\end{array}$} \\
\hline $\begin{array}{l}\text { Search keywords combinations across the title, abstract } \\
\text { and index key words }\end{array}$ & Title & Abstract & 0 \\
\hline "SDG"/"sustainable development goal" + "project" & 0 & 47 & 0 \\
\hline $\begin{array}{l}\text { "SDG"/"sustainable development goal" + "project } \\
\text { management" }\end{array}$ & 0 & 0 & 0 \\
\hline "SDG"/"sustainable development goal" + "infrastructure" & 2 & 27 & 153 \\
\hline "sustainable development" + "project" & 10 & 163 & 78 \\
\hline "sustainable development" + "project management" & 1 & 12 & 65 \\
\hline "sustainable development" + "infrastructure" & 5 & 89 & 129 \\
\hline "sustainability" + "project" & 53 & 395 & 76 \\
\hline "sustainability" + "project management" & 10 & 43 & 100 \\
\hline "sustainability" + "infrastructure" & 17 & 227 & 607 \\
\hline "sustainable infrastructure" & 11 & 17 & \\
\hline Total items & 109 & 1020 & \\
\hline Total & 1736 & & \\
\hline
\end{tabular}

selected journals). As part of the search, we used the following keywords: 'sustainable development goal', 'sustainable development', or 'sustainability' in conjunction with 'project', 'project management' or 'infrastructure' (from 2015-2020). The choice of the six keywords was based on clear differentiation of SDG and IP terminology, but also the need to limit the selection to a manageable data size for analysis. These keywords were searched within the fields of 'title', 'abstract' and 'index key words' as defined by the Scopus search engine. This yielded 1651 articles, shown in the table below (as at February 2020).

The occurrence of searched keywords in relation to one another is displayed in detail below, in respect of the title, abstract and index key words (see Table 1: Items containing combinations of keywords). Some duplications of items containing a combination of more than two keywords were resolved.

To filter out less relevant articles from our sample, we created a subset based on the occurrence of the combinations of keywords, in both title and abstract, as represented in Table 2 . The resultant abstracts were browsed for relevance, which eliminated numerous articles (most of which were focused on pedagogies and training around sustainable development goals, or sustainability projects and initiatives in noninfrastructure sectors).

The 32 articles represent the final subset analysed. These were included in the final review dataset that followed the SLR approach adopted by Jarvis et al. (2003) that codifies data using relevant thematic frameworks, which in the case of this paper, was based on the SDG-IP thematic

Table 2 The resultant reduction of dataset based on combination of keywords

\begin{tabular}{|l|l|l|}
\hline $\begin{array}{l}\text { Subset delineators: } \\
\text { Combined keywords }\end{array}$ & $\begin{array}{l}\text { Total } \\
\text { items }\end{array}$ & $\begin{array}{l}\text { Relevant } \\
\text { articles }\end{array}$ \\
\hline $\begin{array}{l}\text { SDG/Sustainable } \\
\text { Development Goal+ Project }\end{array}$ & 42 & 12 \\
\hline $\begin{array}{l}\text { SDG/Sustainable } \\
\text { Development Goal+ } \\
\text { Infrastructure }\end{array}$ & 22 & 16 \\
\hline $\begin{array}{l}\text { SDG/Sustainable } \\
\text { Development Goal+ Project } \\
\text { + Infrastructure }\end{array}$ & 5 & 4 \\
\hline & $\mathbf{6 9}$ & $\mathbf{3 2}$ \\
\hline
\end{tabular}


structure, codifying key information in relation to seven areas of interest:

1. Type of contribution (such as framework proposition, framework testing, exploratory, theoretical, etc.).

2. Research design (namely, empirical, single/multiple case study, systematic literature review, etc.).

3. Primary geographical focus of study (ie, where the study took place or was focused).

4. Primary infrastructure sector (eg, water, energy, transport, etc.).

5. Primary industry (if applicable; eg, airports).

6. Relevant institutional level (eg, regional, national, organisational, etc.).

7. Sustainable Development Goals mentioned in the article.

The summary data across the 32 articles codified against the seven SDG-IP thematics is included as Appendix 1. The results from this analysis are captured and discussed in the following section. The analysis has been completed at two levels: level one examines the dataset of 32 articles across the seven SDG-IP thematics and level two provides a deeper analysis of the 13 most relevant articles, based on their prevalence of keyword combinations, across SDG-IP research issues and themes.

\section{RESULTS and DISCUSSION}

Quantity of Relevant Articles in Dataset

The analysis of the dataset, illustrated in Figure 4, showed that within this sample, there were identifiable differences and similarities. For example, across the four sustainability journals there was a total of 1426 articles which equates to 285 articles per sustainability journal. This compares with a total of 204 across the policy journals. The least represented were the project management journals that had a total of 21 articles.

\section{Quantity of Use of Keywords in Ab- stracts Over Time}

The dataset enabled the capture of the prevalence of keywords used over the selected time period of 2015 - February 2020, as shown in Figure 5. The value for researchers in this field is that it highlights the rapid increase in some keywords, especially in the past two years, and suggests that this is an increasing area of importance and relevance. For example, the prevalence of 'SDG' has increased by a factor of 29 with most of the increase in the last two years. Similarly, the appearance of the keywords of 'sustainable development' have increased by a factor of five and 'sustainability' by a factor of three. The latter two keywords have also had a noticeable inflection point in 2017, that is

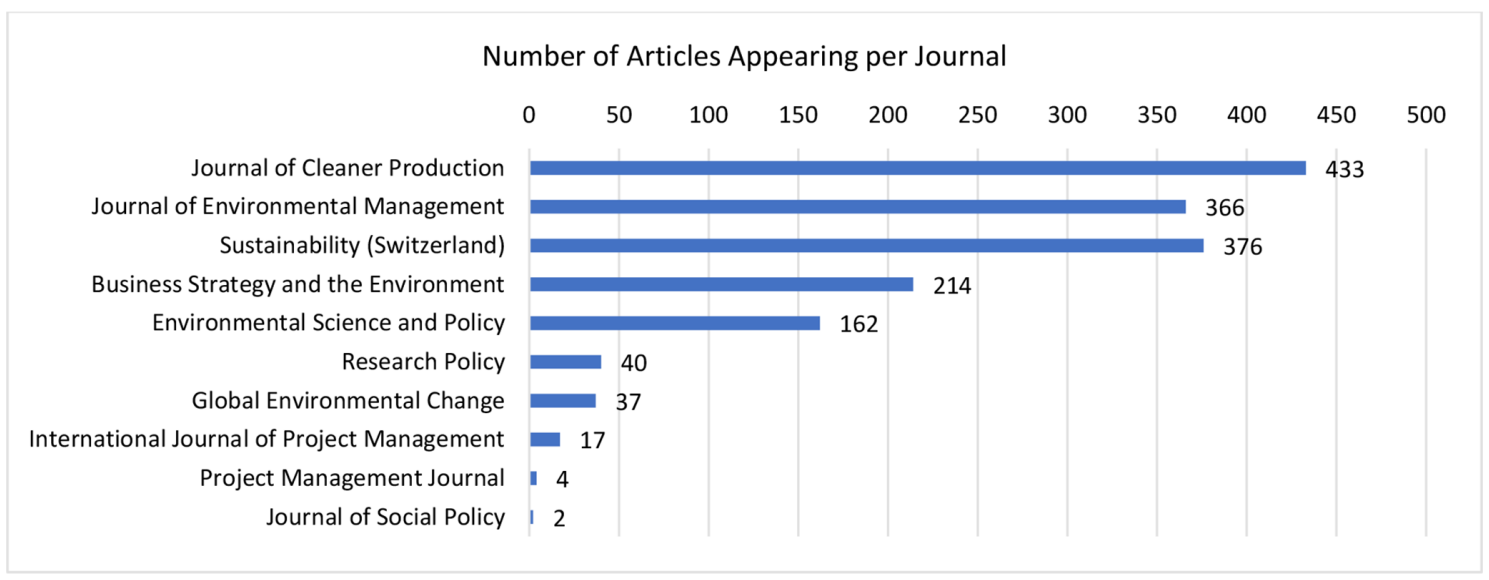

Figure 4 Occurrences of articles appearing in selected journals using the keywords. 


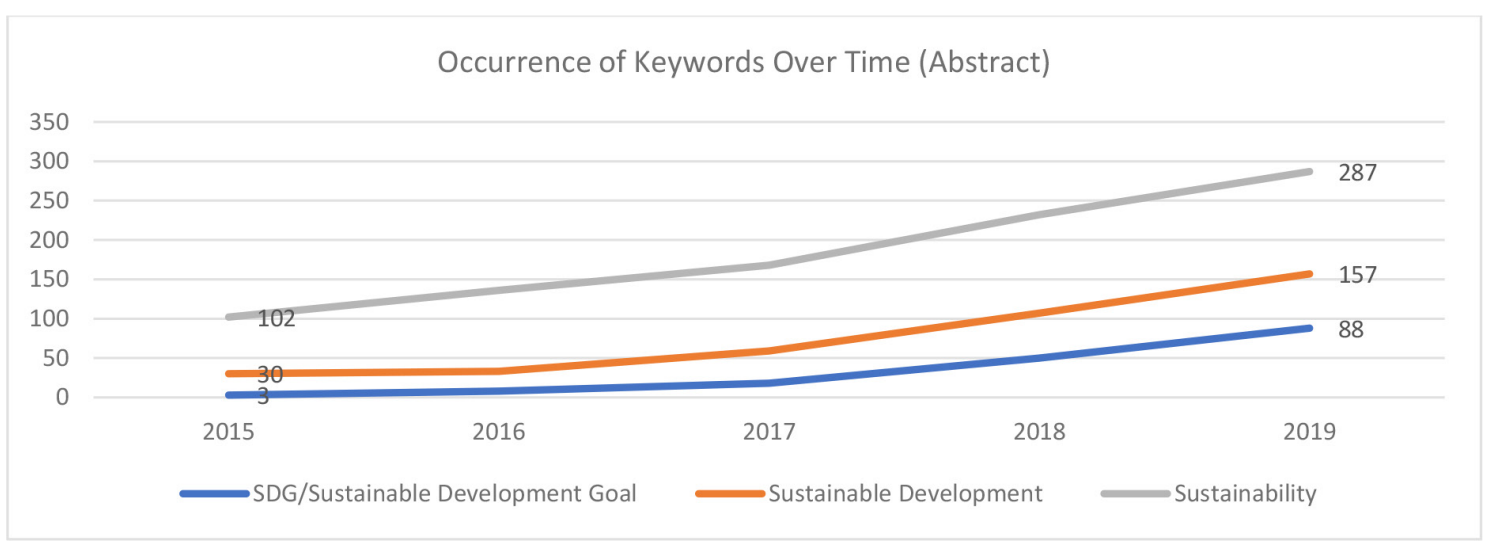

Figure 5 Occurrence of Keywords in abstracts over time.

most likely due to the increasing recognition of the SDG terminology since their introduction in 2015.

\section{Level 1 Analysis: Results Across the Seven Codified SDG-IP Thematics}

This section covers the analysis of the seven thematic areas identified in the earlier part of this SLR.

\section{SDG-IP thematic 1: Type of contribution (framework proposition, framework test- ing, exploratory, theoretical, etc.)}

Since the aim of this paper is to evaluate the state of knowledge on the specific SDG-IP topic, it is useful to identify what approaches have been used to evaluate this area. The purpose was to create relevant research agendas, based on any identified gaps in research, or seek insights that will facilitate the next level of research. In this way, it has been proposed (Baumeister and Leary, 1997; Torraco, 2005) that literature reviews are useful to develop theory and conceptual models.

The results showed a pre-dominance (over $60 \%$ ) of articles were based on Framework Testing (in this context a framework means an analytical tool to support a research study) and Framework Propositions, but there were fewer Theoretical article and Exploratory methods. This might suggest that there is confidence in existing theories, and that new frameworks are being developed to harness the theories more effectively for the emerging demands of the IP-SDG topic. While there is not necessarily an SDG-IP research gap in the type of contributions, the findings might highlight the preference for frameworks as a way to engage with practitioners that are seeking tools to effect improved ways of measuring SDG impacts on IP.

\section{SDG-IP thematic 2: Research design (em- pirical, single/multiple case study, system- atic literature review, etc.)}

The analysis of SDG-IP Thematic two on research design used these five headings (shown in Figure 6) to give a high-level quantification of design use. This illustrates that empirical analysis was the most favoured approach, and that two thirds of articles used case studies in some form.

The results showed that empirical analysis was the favoured approach followed by multi-case studies and single studies, thus indicating that two thirds of articles used case studies in some form. Drawing conclusions on future research focus from these findings is informed by Tranfield et al. (2003) who contend that many SLRs have researcher bias, lack rigour and have insufficient empirical evidence to underpin insights that could enable intervention

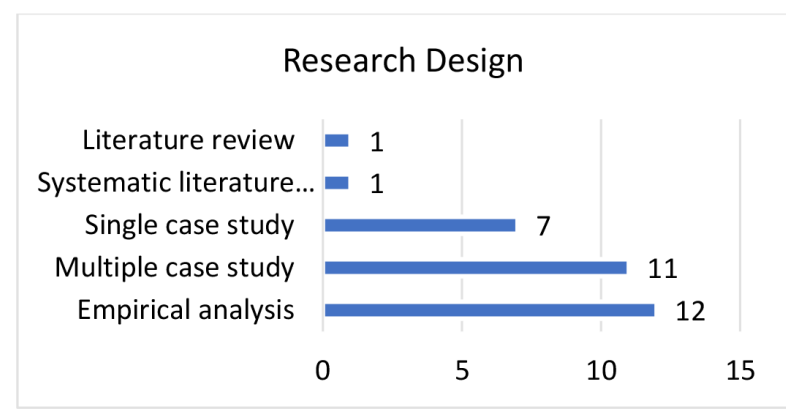

Figure 6 Research design approaches. 
into the practitioners' operational roles. The results of this thematic area therefore underpin the increasing emphasis towards using empirical evidence and case studies. This suggests that future research should seek design methods that relate to practitioners and thereby help inform the SDG-IP policy formulation and implementation.

\section{SDG-IP thematic 3: Primary geographical focus of study (where the study took place or was focused)}

The geographical spread of the articles was significant. There were eleven articles that had a focus on BRIC (Brazil, Russia, India, China, and South Africa) countries and only two from OECD (Organisation for Economic Co-operation and Development) countries. There were also some outliers that included Mozambique, Curacao, Ethiopia and Somalia. The balance of articles between developed countries $(n=26)$ and developing countries $(n=4)$, with a smaller number having a global focus, shows that there remains a predominance of research in the more accessible databases of developed countries.

The larger data set of articles from and of developed countries indicates a prevalence of research due to more accessible databases of developed countries as well as a larger body of research resource capacity. There is an opportunity to close the gap by focusing more research resources on developing countries since that is where many of the greatest SDG challenges are situated (Organisation for Economic Co-Operation and Development (OECD), 2019; United Nations, 2018).

\section{SDG-IP thematic 4: Primary infrastructure sector (eg, water, energy, transport, etc.)}

The representation across the infrastructure sector showed (in Figure 7) a dominance of water-focused articles $(n=9)$, followed by urban development $(n=6)$ and energy $(n=4)$. The remaining eleven areas had a combined total of one less article $(n=18$, versus $n=19$ ) of the top three areas. In some cases, the article covered more than a single sector, hence the increased total above the 32 articles analysed.

The dominance of water-focused, urban development and energy articles suggests key SDG-related IP, such as health (SDG 3 - Good Health and Wellbeing) are under-represented and perhaps, the key enabling IP areas such as roads, housing, sanitation, are also research areas that would benefit from increased focus.

\section{SDG-IP thematic 5: Primary industry (e.g. airports)}

The more detailed analysis of each article was carried out to identify their specific subsector focus

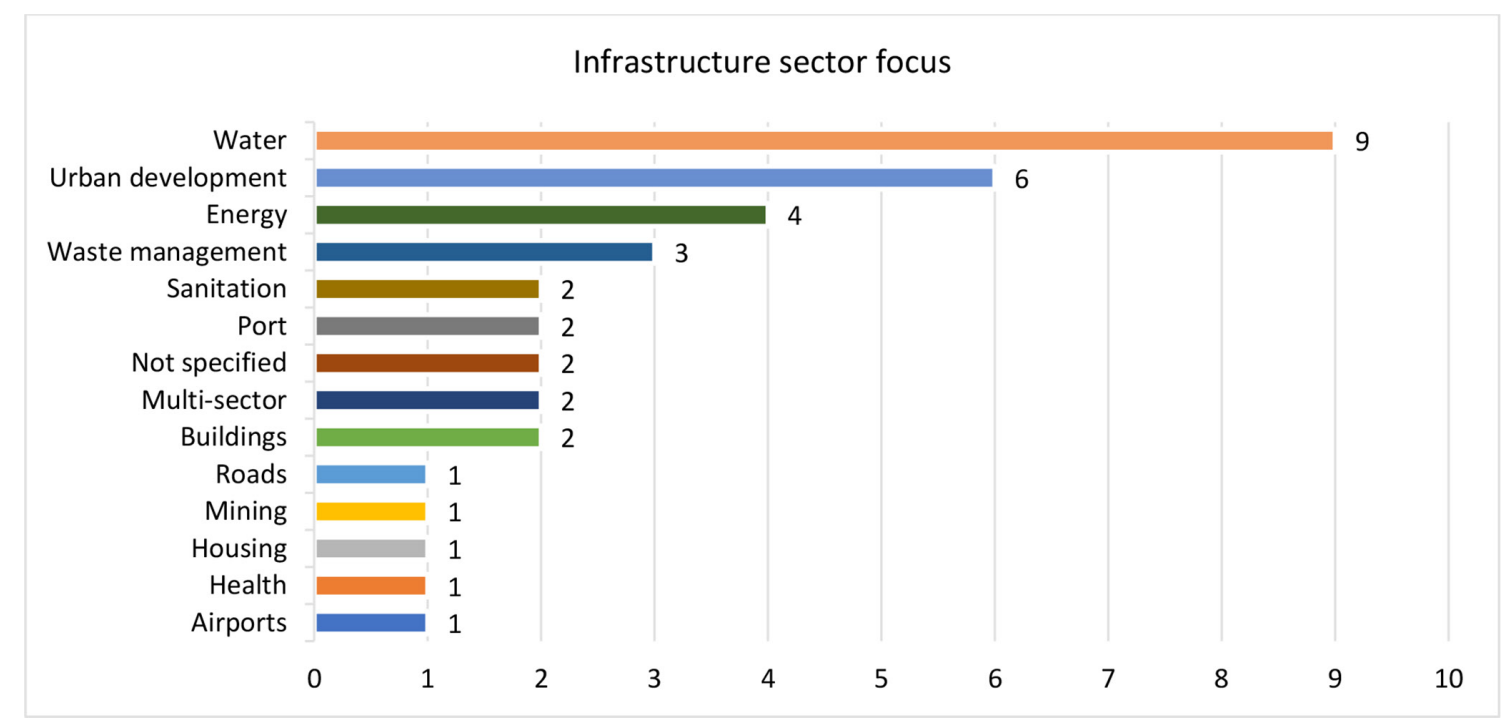

Figure 7 Sectoral focus of subset articles. 
provided less definitive findings. For example, whilst the prevalence of water sector IP articles illustrated that there were six areas of subcategories used (namely rural water services; transboundary resources; water transfer; river basins and water quality; water supply, solid waste), there was little value gained from further analysis of the other sectors.

The sample set was too narrow to make any significant conclusions from the results but to some extent, the results indicated that the spread of subsector topics in articles is broad, if not deep, across sub-sectors. An opportunity might exist to compare the IP related sub-sector topics with SDG goals and targets, to seek research alignment, for example, analysing SDG targets for SDG 6 (Clean Water and Sanitation) could highlight specific topics related to the targets and their indicators that deserve greater focus. In this case, Target 6.1, 'By 2030, achieve universal and equitable access to safe and affordable drinking water for all', has indicator 6.1.1, measuring the 'Proportion of population using safely managed drinking water services', which could provide a structured way of narrowing the focus for deeper research into specific sub-sector topical areas.

\section{SDG-IP thematic 6: Relevant institutional level (eg, regional, national, organisational, etc.)}

The analysis of the dataset of articles (see Figure 8) indicates that there is less research conducted at the higher and lower ends of the hierarchy. For example, the top levels from global-national spanned 15 articles, the lower level from sectorproject spanned 11 articles whilst the middle three levels from national to industry included 20 articles.

The concentration of articles in the central area is not necessarily surprising but it does highlight the paucity of research at the lower levels that this paper seeks to clarify. This suggests that at the organisational level there is better coverage but that a gap exists at the sector-project level. An existing framework for the analysis across levels is provided by Müller et al. (2019) in their organisational levels in project management (OPM) model. In project management terms, this includes the project, programme, and portfolio levels of organisational design and this could allow the alignment of the IP-SDG analysis with the Müller-developed theory to help explain the SDG interface and interaction of the OPM elements across the layers within the model.

\section{SDG-IP thematic 7: Sustainable Develop- ment Goals mentioned in the articles}

The final of the seven SDG-IP thematic themes was a numeric counting of which specific SDGs (of the 17 goals) were the focus of the articles in the dataset. Unsurprisingly, given the heavy sectorial focus on water in the dataset, SDG six on Clean Water and Sanitation, was the most prevalent $(n=6)$. This was followed by SDG 11, Sustainable

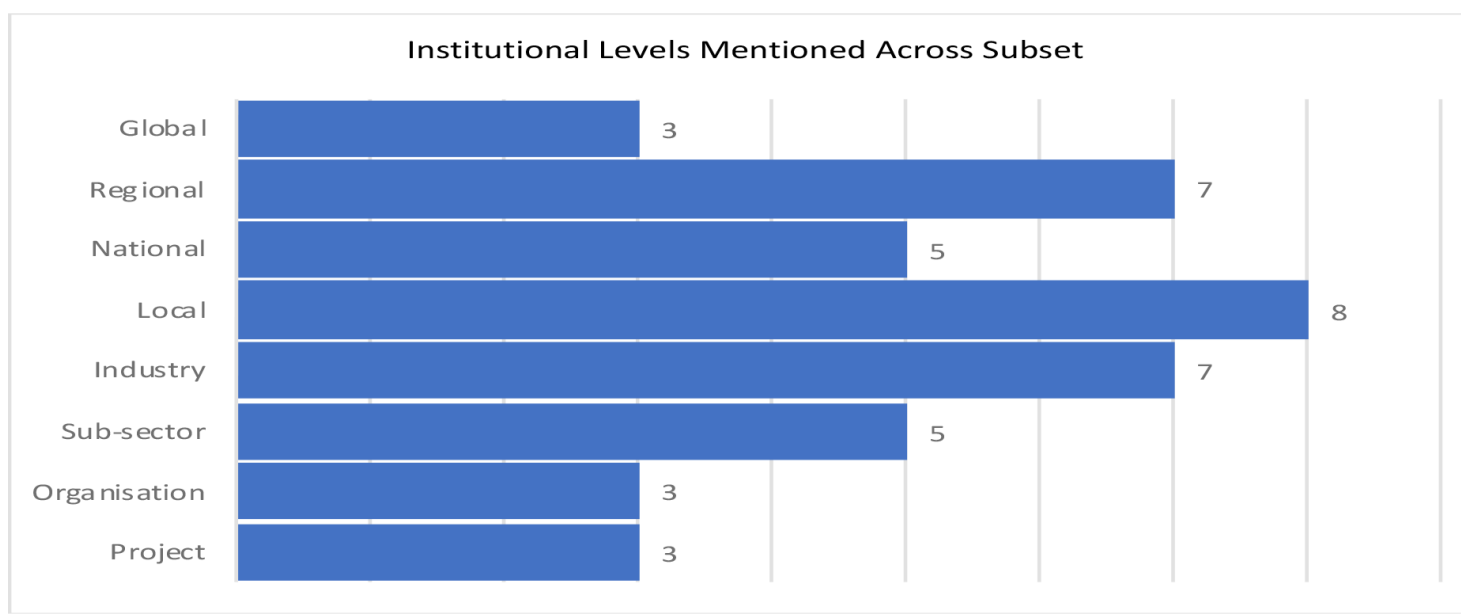

Figure 8 Institutional focus of subset articles.

Engineering Project Organization Journal

(C) 2021 Engineering Project Organization Society www.epossociety.org 
Cities and Communities, which aligns closely with the search parameters of IP $(n=4)$. Eight articles referred to SDGs in a general reference without a specific focus on individual SDGs and six of the SDGs were specifically mentioned in the articles but with lower occurrence.

The results on this thematic suggests that there is an opportunity to broaden the research across the SDGs that were under-represented, specifically into those SDGs identified as being most affected by the development of infrastructure, or, to deepen the research in areas already covered, such as SDG six or 11 .

\section{Level 2 Analysis of the 13 Top SDG-IP Articles Based on Their Keyword Oc- currences}

Whilst the SLR methodology used in the preceding sections has been mostly based on the rules and standards proposed by Liberati et al. (2009), it has only provided a high-level indication of where the future research opportunities might lie. Therefore, the semi-systematic review process, sometimes referred to as a 'narrative review approach' is used for topics that have been conceptualised differently and researched by groups across diverse disciplines. This approach does not easily fit with a full systematic review process as advocated by Wong (2013), which suits the purposes of a Level two analysis. This is because it enables the tailoring of the research to the specific needs of the project, which in this case involves the further de-selection of articles to the most relevant based on their prevalence of keywords. The articles are then analysed to identify SDG-IP issues and sub-issues that have relevance in guiding future research opportunities in the SDG-IP field. The data in Figure 9 highlights the correlation between the issues and sub-issues and the author reference of where the sub-issues are derived from in the top 14 research articles. This provides future researchers the opportunity to build on these identified themes to derive new SDG-IP insights. A summary of all the relevant extracts from the top 13 articles is included at Appendix 2 and full data screenshot is shown at Appendix 3 of the 1651 artefacts.

Analysis of the nodal framework shown in Figure 9 indicates that there is a balanced spread of the top articles that relate to the identified SDG-IP research issues although there are three

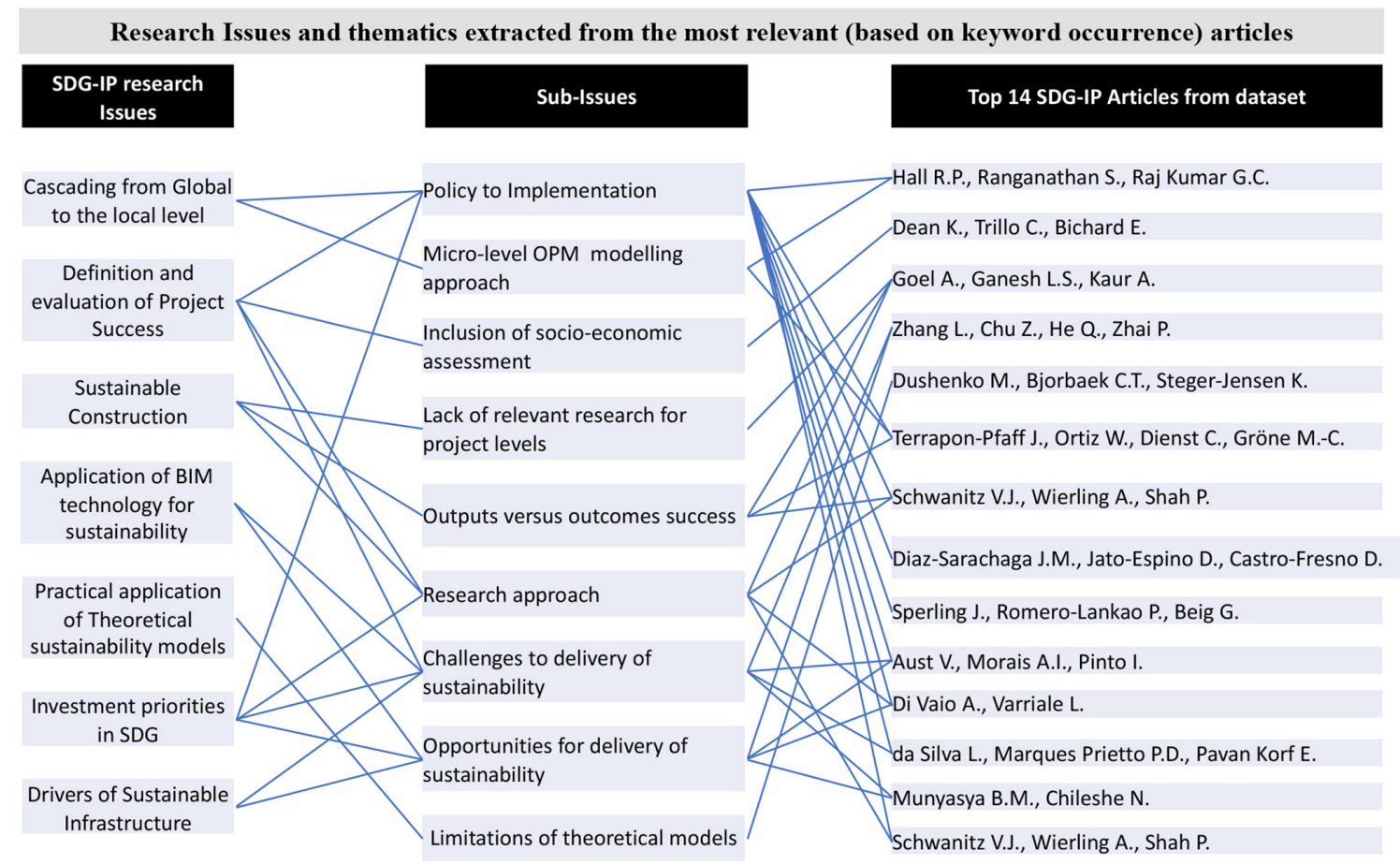

Figure 9 Research Issues and sub-issues based on the 13 most relevant articles. 
that dominate: 'definition and evaluation of project success' $(n=4)$; 'sustainable construction' $(n=3)$; and 'investment priorities in SDGs' $(n=3)$. There is clearer differentiation of the most common sub-issues across the research themes: "policy to implementation' $(n=8)$; 'research approach' $(n=4)$; 'opportunities for delivery of sustainability' $(n=4)$; 'challenges to delivery of sustainability' $(n=4)$; and 'outputs versus outcomes' $(n=3)$.

\section{What Research Themes Have Emerged From the SLR?}

The research study has sought to explore opportunities for research into the assessment of Infrastructure Projects through SDG targets. We adopted an SLR methodology to examine a subset of relevant journal articles to understand the quantitative data across 7 SDG-IP thematic areas. We then developed a Level two analysis to identify some qualitative insights into the type of issues that have been covered within the sample set.

The following sections will explore the themes that have been examined through the SLR process and consolidate emerging opportunities for further research. The answer to the first question is provided from analysis of the SLR results of the seven thematic criteria. The second and third questions are answered using the Level 2 analysis of the 13 top articles.

\section{(1) How extensive (broad and deep) has the research into SDG-IP been to-date?}

The Level one analysis has indicated that there is a growing body of research into SDG-IP, with a marked increase since 2017. The relative coverage of the SDG-IP, against other business and project management research areas is less easy to quantify since SDGs have only been in existence since 2015 and the SDG targets and indicator framework was only fully agreed by the 193 signatory nations in 2016. However, recent SLR studies (Aarseth et al., 2017; Engert et al., 2016) have shown that sustainability in a project context is still a nascent and fragmented research area, but that there is growing awareness of its criticality to business success, and indeed, also to society and environmental success. This reinforces the contention that SDG-IP research is 'nascent' to an even greater degree because there were approximately $300 \%$ more sustainability keyword connections than for SDGs.

\section{(2) What issues and sub-issues were iden- tified that might inform a future thematic framework to support more systematic research in the field?}

The level two analysis has provided useful insights into the issues and sub-issues that emerged from the qualitative analysis of the highest ranked articles in the dataset. The diagram below (Figure 10) illustrates the research themes that were developed from the SLR.

Whilst the analysis of the individual articles indicated their specific research focus areas, the overview across all the research articles provided a strategic perspective of linkages between the issues, sub-issues and derived supra-themes. In many cases the studies did not overtly cover these areas, and this could be evidence of a research gap. More helpful for future research is an emerging research framework that provides a strategic context to analyse the assessment of SDGs on IP. To give an indication of how this might be used, the sections below provide an overview of the main points emerging from five of the seven "SDG-IP Research Issues" shown in Figure 10 in the left column.

\section{SDG-IP future Research Issue 1. Cascading from global to the local level}

As shown in Appendix 2 and Figure 12, there were 4 of the top 13 articles that had a research focus on understanding the link from global to local level. For example, Hall et al. (2017) examined how to operationalise SDG goals-targets through IP, both at organisational and government levels. This was similar to Terrapon-Pfaff et al. (2018) who also sought to look further down the hierarchical levels, specifically on the WEF [water-energy-food] nexus discussions which they noted had rarely been cascaded below national or global levels. This new research provides insights to 'macro-level drivers, material flows and large Infrastructure developments', which they contend is the critical 


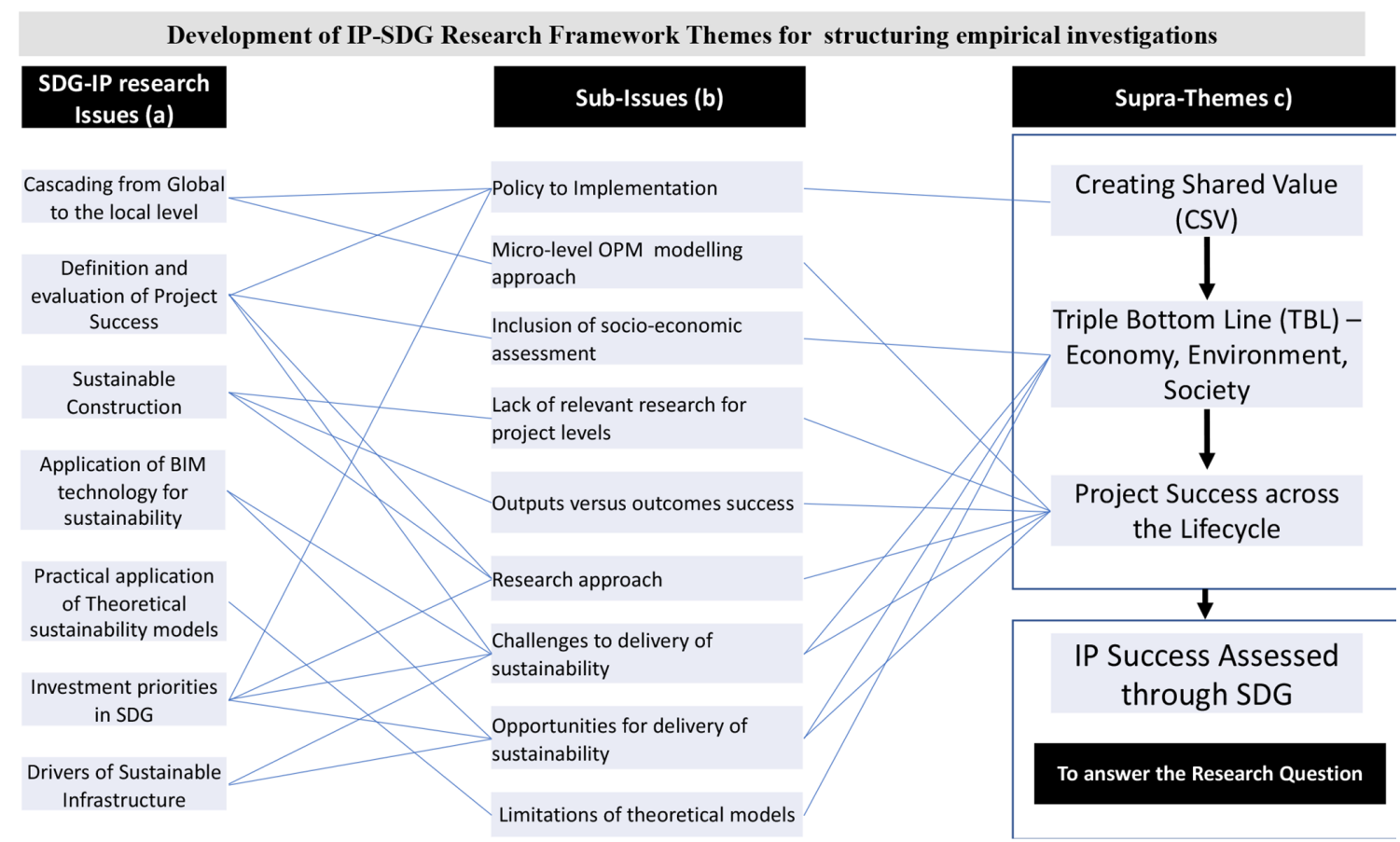

Figure 10 Structure of issues, sub-issues and emerging supra-themes.

requirement of research because 'major nexus challenges are faced at local level'.

\section{SDG-IP future Research Issue 2. Definition and evaluation of Project Success}

Dean et al. (2017) considered the definition of project success is currently too narrow and concluded that the inclusion of socio-economic assessments, as well as environmental, were needed to derive improved investment decisions, exclaiming that "current evaluative methods that support decision making on social housing interventions fail to capture all of the socio-environmental value contained in the UN SDG 11". Their study addressed the issue by demonstrating how Sustainable Return on Investment can successfully describe and analyse a range of externalities related to the sustainable value generated by social housing regeneration schemes. This view was complemented by Schwanitz et al. (2017) and Diaz-Sarachaga et al. (2016) where both research teams analysed the fundamental basis for investment decisions. In the first case, the article considers the green rating systems and the impact of an absence of meaningful metrics, while the second explores other sustainability assessment tools such as LEED ND and Envision, suggesting that both are lacking in one of the triple bottom line areas of economic, societal or environmental dimensions. The latter study is supported by Schwanitz et al. (2017) who proposed further work was needed to develop relevant 'indicators and visualisation methods' that are relevant for IP at sub-national level. A third study that highlighted the need for harmonised indicators was the da Silva et al. (2019) team, which aimed to develop a 'relevant set of sustainability indicators to analyse municipal solid waste management (MSWM) in large and medium-sized worldwide cities'. They also highlighted the need for better information databases that were currently insufficient for the sectors' needs.

\section{SDG-IP future Research Issue 3. Sustaina- ble Construction}

Goel et al. (2019) noted that few research studies analyse the literature of sustainable construction (SC) in India. They identified both a thematicknowledge research gap and also a geographical and sector gap. This provides a useful line of future research opportunities, where both thematic and geographical gaps can be addressed by a single research study. This would typically be the objective of most research agendas, to find a 
Table 3 Proposed questions for further research

\begin{tabular}{|c|c|}
\hline SLR reference & $\begin{array}{l}\text { Research questions \& Themes } \\
\text { Envisaged practical applications of research }\end{array}$ \\
\hline $\begin{array}{l}\text { SDG-IP Research Issue 1. Cascading from Global } \\
\text { to the local level (Governance) } \\
\text { Hall et al., 2017; Terrapon-Pfaff et al., } 2018\end{array}$ & $\begin{array}{l}\text { - How does the OECD definition of governance } \\
\text { and the underlying principles of governance effect the } \\
\text { measurement of projects'SDG impact? } \\
\text { ' Who are the major governance stakeholders and } \\
\text { shareholders that influence the measurement of SDGs } \\
\text { beneath global-national levels, at the organisational- } \\
\text { project level? } \\
\text { How does the theory of a temporary organisation } \\
\text { effect the measurement of SDGs at project level as } \\
\text { compared to the organisational level? }\end{array}$ \\
\hline $\begin{array}{l}\text { SDG-IP Research Issue 2. Definition and evaluation } \\
\text { of Project Success } \\
\text { Dean et al., 2017; Diaz-Sarachaga et al., 2016; } \\
\text { Schwanitz et al., 2017; da Silva et al., } 2019\end{array}$ & $\begin{array}{l}\text { Does the current definition of project success } \\
\text { place sufficient value in the wider criteria across } \\
\text { environmental and societal factors as well as existing } \\
\text { economic drivers? } \\
\text { - If there is insufficient effective action in measur- } \\
\text { ing SDGs, how is the governance model strengthened } \\
\text { to drive greater success at project level? } \\
\text { - What understanding had been derived from the } \\
\text { research into projects'benefits management and how } \\
\text { might this effect the successful measurement of SDGs } \\
\text { on projects? }\end{array}$ \\
\hline $\begin{array}{l}\text { SDG-IP Research Issue 3. Sustainable Construction } \\
\text { Goel et al., 2019; Munyasya and Chileshe, } 2018\end{array}$ & $\begin{array}{l}\text { What research across the engineering and in- } \\
\text { frastructure sector that has focused on measurement } \\
\text { of sustainability success on projects can be used for } \\
\text { assessment of SDG-IP impact? } \\
\text { - What existing tools and processes (eg, LEED, En- } \\
\text { vision, CEEQUAL) could be utilised for the assessment } \\
\text { of SDG-IP impact? }\end{array}$ \\
\hline $\begin{array}{l}\text { SDG-IP Research Issue 4. Practical application of } \\
\text { Theoretical sustainability models } \\
\text { Dushenko et al., 2018; Tranfield et al., } 2003\end{array}$ & $\begin{array}{l}\text { - What empirical evidence has been collated in } \\
\text { relation to SDG-IP issues that can be used to drive } \\
\text { practical solutions to SDG-IP challenges? } \\
\text { - What theoretical or concept models developed for } \\
\text { the project management community for the identif- } \\
\text { cation and measurement of benefits could be used to } \\
\text { support practical SDG-IP assessments? }\end{array}$ \\
\hline $\begin{array}{l}\text { SDG-IP Research Issue 5. Investment priorities in } \\
\text { SDG } \\
\text { Aust et al., } 2020\end{array}$ & $\begin{array}{l}\text { What are the international contextual issues (po- } \\
\text { litical, cultural, environmental and social) that effect } \\
\text { the measurement of SDG impacts at Infrastructure } \\
\text { project level? } \\
\text { that inform decisions in sustainable infrastructure and } \\
\text { how might the existing frameworks be utilised for the } \\
\text { SDG-IP assessment challenge? }\end{array}$ \\
\hline
\end{tabular}

Engineering Project Organization Journal

(C) 2021 Engineering Project Organization Society

www.epossociety.org 
new area of study that their research can inform and positively impact future practical changes. Munyasya and Chileshe (2018) also highlighted that whilst there were plenty of research studies on sustainable infrastructure, there are few on the influencing drivers and barriers particularly within the South Australian construction industry'. They identified a research gap across three areas: 'the lack of steering mechanism, multi-disciplinary nature of the word "sustainability", and lack of cooperation and networking' which they considered major barriers.

\section{SDG-IP future Research Issue 4. Practical application of theoretical sustainability models}

As mentioned earlier, there are those, such as Tranfield et al. (2003), who contend that many SLRs have insufficient empirical evidence to underpin insights that could enable intervention into the practitioners' operational roles. In short, they don't add value to the practitioners' world thereby undermining the essence of research value-add. In this regard, Dushenko et al. (2018) postulate that there is an over preponderance on theoretical models that don't have practical application. This provides a research opportunity to assess existing theoretical sustainability models that might be used for SDG-IP needs. There are models, such as a theoretical model to build a logical framework to map the inputs of a project to the expected 'ends' of the projects' outcomes. The Logframe model might be an example of an existing conceptual model that could be harnessed.

\section{SDG-IP future Research Issue 5. Invest- ment priorities in SDG}

Aust et al. (2020) start from the proposition that IP are critical to make serious impacts on the 2030 Agenda of Sustainable Development. They specifically examine the use of foreign direct investment (FDI) as a source of external financing in the private sector across 44 African countries. This builds on the suggestions for future research from the Level 1 Analysis that research resources from the developed world could, and should, be utilising more of their capacity and capabilities

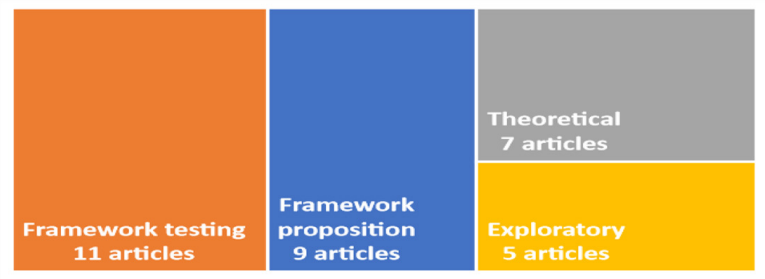

Figure 11 Type of contributions, using a hierarchical treemap chart, across subset.

to examine the SDG-IP knowledge gap across developing countries. They contend that their study assists decision-makers with investment plans to achieve the SDGs, which aligns with the Research issues 2 and 4 in that they also focus on practical solutions emanating from SDG-IP research studies to encourage, as Aust et al., state: 'further investments in Africa and progress against the SDGs'.

\section{(3) How could such a framework be used to provide guidance to a range of stakeholders (including regulators, policymakers, academia, investors and infrastructure practitioners) on how to align IP and their impacts to the SDGs?}

A recurring theme emanating from analysis of the selected articles is the need to make the research accessible and relevant to the practitioner community of stakeholders, whether policy makers, investors, project managers or others. Indeed, there was a specific thematic area that was identified as SDG-IP Research Issue 4: Practical application of Theoretical sustainability models, which is a theme Tranfield et al. (2003), championed. The collective wisdom from these papers has been to seek research opportunities to assess existing theoretical sustainability models that might be used for SDG-IP needs.

The focus on practical application of research can be supported by the emerging list of possible questions that this SLR article has informed. The list of questions in Table 3 is preliminary but gives a view of the proposed 'direction of travel'. 


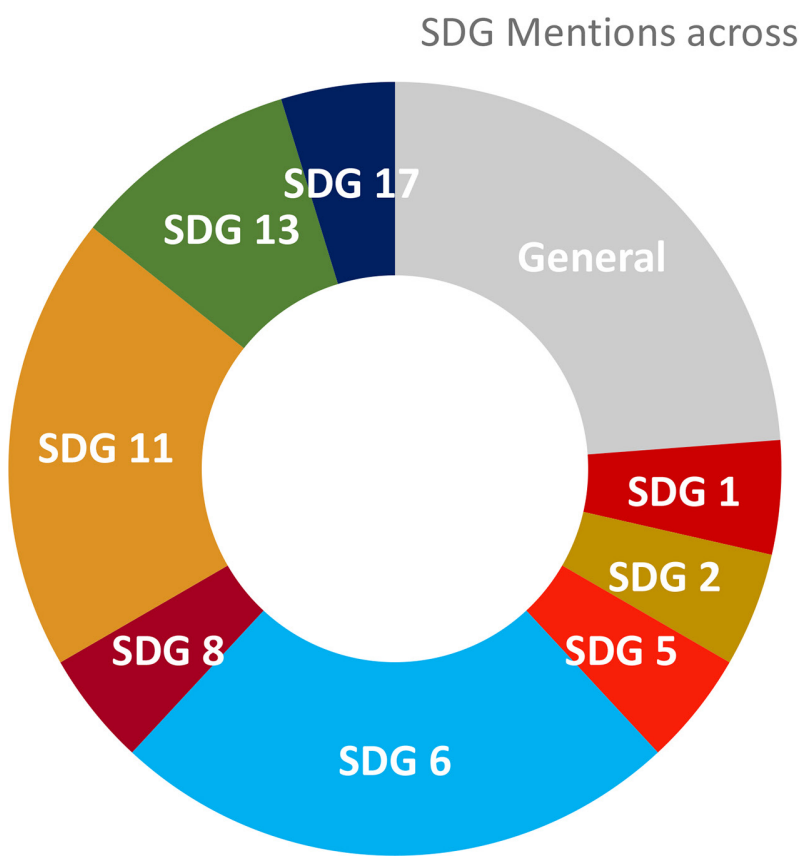

General General

SDG 1 No poverty

SDG 2 Zero hunger

SDG 5 Gender equality

- SDG 6 Clean water and sanitation

SDG 8 Decent work and economic growth

- SDG 11 Sustainable cities and

communities

SDG 13 Climate action

SDG 17 Partnership for the goals

Figure 12 SDG mentions across subset.

\section{CONCLUSION}

In the context of climate change as an existential threat to the human race, alongside the COVID19-exacerbated threats of growing social and economic inequalities, rising social tensions, and mass migration (United Nations Intergovernmental Panel on Climate Change (IPCC), 2018), the international community has responded to the

Table 4 Items containing keywords, in the database per Journal

\begin{tabular}{|l|r|}
\hline Journal & Total \\
\hline Journal of Cleaner Production & 433 \\
\hline Journal of Environmental Management & 366 \\
\hline Sustainability (Switzerland) & 376 \\
\hline Business Strategy and the Environment & 214 \\
\hline Environmental Science and Policy & 162 \\
\hline Research Policy & 40 \\
\hline Global Environmental Change & 37 \\
\hline International Journal of Project Management & 17 \\
\hline Project Management Journal & 4 \\
\hline Journal of Social Policy & 2 \\
\hline & 1651 \\
\hline
\end{tabular}

grand challenge of sustainable development with the '2030 Agenda for Sustainable Development', culminating in 17 Sustainable Development Goals, linked to 169 targets and 231 (unique) indicators. The IPCC has identified that "directing finance towards investment in infrastructure for mitigation and adaptation" is key to meeting SDG targets (2018) and the estimated USD \$94 trillion infrastructure investment that is required globally between 2018 and 2040 (Global Infrastructure Outlook, 2019), represents a significant opportunity to stimulate economic prosperity, reduce poverty and raise standards in living, health, education and gender equality. This is relevant for the project management community, a critical profession in the delivery of infrastructure through projects across all sectors, and thus in development.

This reason has motivated an overarching enquiry in opportunities for research into the assessment of IP through SDG targets, distilled through three research questions: (1) How extensive (broad and deep) has the research into SDG-IP been to-date? (2) What issues and sub-issues were identified that may inform a future thematic framework to support more systematic research in the field? (3) How could such a framework be used to provide guidance to a range of stakeholders 
Table 5 Data analysis of key words tabulated across the two dimensions of SDG and IP.

\begin{tabular}{|l|c|l|c|}
\hline Data capture in Title & Project & Project Management & Infrastructure \\
\hline SDG/Sustainable Development Goal & 0 & 0 & 2 \\
\hline Sustainable Development & 10 & 1 & 5 \\
\hline Sustainability & 53 & 10 & 17 \\
\hline Data capture in Abstract & & & 27 \\
\hline SDG/Sustainable Development Goal & 47 & 0 & 89 \\
\hline Sustainable Development & 163 & 12 & 227 \\
\hline Sustainability & 395 & 43 & \\
\hline Data capture in Index Key Words & & & 6 \\
\hline SDG/Sustainable Development Goal & 0 & 0 & 100 \\
\hline Sustainable Development & 153 & 78 & \\
\hline Sustainability & 129 & 76 & \\
\hline
\end{tabular}

(including regulators, policymakers, academia, investors and infrastructure practitioners) on how to align IP and their impacts to the SDGs? Question one was answered through a Level 1 analysis of an SLR, which identified 7 SDG-IP thematic areas. Questions 2 and 3 were answered using the Level 2 analysis of the 13 top articles.

The analysis identified the recurring need to make research accessible and relevant to the practitioner community by pursuing studies that will result in practical applications for theoretical sustainability models. This culminated in the proposal of several research questions across the emergent research issues: the importance of localising assessment; defining project success in light of the SDGs; expanding on sustainable construction research; driving practical assessment solutions and benefits for stakeholders; and prioritising investment into SDG assessment where it is most critical, both thematically in terms of specific SDGs, as well as geographically, with a renewed focus on developing countries where sustainability challenges abound. With a focus on IP, this study finds that SDGs are seldom linked to projects (either in delivery or in their outputs and outcomes) and we suggest that increased knowledge in this area may improve both IP investment decisions and performance against SDGs. The framework presented thus guides the advancement of meaningful research into the assessment of IP through an SDG lens. In regard to future work it is suggested that further research is required in order to develop an integrated framework to link global level SDGs with project level features and outputs. Such a framework should then be tested through appropriate empirical studies, such as through a large-scale survey of practitioners engaged on IP delivery as well as through case study research on mega projects that need to be linked to the achievement of SDG outcomes.

\section{References}

Aarseth, W., Ahola, T., Aaltonen, K., Økland, A. and Andersen, B. (2017), "Project sustainability strategies: a systematic literature review", International Journal of Project Management, Vol. 35 No. 6, pp. 1071-1083. 10.1016/j.ijproman.2016.11.006

Ainger, C.M. and Fenner, R.A. (2014), Sustainable infrastructure: principles into practice. London, UK: ICE publishing.

Anwar, B., Xiao, Z., Akter, S. and Rehman, R.-U. (2017), "Sustainable urbanization and development goals strategy through Public-Private partnerships in a South-Asian Metropolis", Sustainability, Vol. 9 No. 11, p. 1940. 10.3390/su9111940

Aust, V., Morais, A.I. and Pinto, I. (2020), "How does foreign direct investment contribute to sustainable development goals? Evidence from African countries", Journal of Cleaner Production, Vol. 245 No. 3, 118823. 10.1016/j.jclepro.2019.118823

Baumeister, R.F. and Leary, M.R. (1997), "Writing narrative literature reviews", Review of General Psy- 
chology, Vol. 1 No. 3, pp. 311-320. 10.1037/10892680.1.3.311

Brundtland, G.H. (1987), "What is sustainable development", Our common future, Vol. 8 No. 9.

Cheng, S., Li, Z., Uddin, S.M.N., Mang, H.-P., Zhou, X., Zhang, J., Zheng, L. and Zhang, L. (2018), “Toilet revolution in China", Journal of environmental management, Vol. 216, pp. 347-356. 10.1016/j. jenvman.2017.09.043

Ciegis, R., Ramanauskiene, J. and Martinkus, B. (2009), "The concept of sustainable development and its use for sustainability scenarios", Engineering economics, Vol. 62 No. 2.

Cooke-Davies, T. (2007), "The "real" success factors on programmes". In: Morris and Pinto, J, ed, The Wiley Guide to Managing Projects. Hoboken, NJ: Wiley. pp. 106-108.

Costanza, R. and Patten, B.C. (1995), "Defining and predicting sustainability", Ecological Economics, Vol. 15 No. 3, pp. 193-196. 10.1016/09218009(95)00048-8

da Silva, L., Marques Prietto, P.D. Pavan Korf, E., Domingos, P. and Prietto, M. (2019), "Sustainability indicators for urban solid waste management in large and medium-sized worldwide cities", Journal of Cleaner Production, Vol. 237, 117802. 10.1016/j. jclepro.2019.117802

Dean, K., Trillo, C. and Bichard, E. (2017), “Assessing the value of housing schemes through sustainable return on investment: a path towards SustainabilityLed evaluations?" Sustainability, Vol. 9 No. 12, p. 2264. 10.3390/su9122264

Di Vaio, A. and Varriale, L. (2018), "Management innovation for environmental sustainability in seaports: managerial accounting instruments and training for competitive green ports beyond the regulations", Sustainability, Vol. 10 No. 3, p. 783. 10.3390/su10030783

Diaz-Sarachaga, J.M., Jato-Espino, D., Alsulami, B. and Castro-Fresno, D. (2016), "Evaluation of existing sustainable infrastructure rating systems for their application in developing countries", Ecological Indicators, Vol. 71 No. 6, pp. 491-502. 10.1016/j. ecolind.2016.07.033

Ding, X., Zhou, C., Mauerhofer, V., Zhong, W. and Li, G. (2019), "From environmental soundness to sustainable development: improving applicability of payment for ecosystem services scheme for diverting regional sustainability transition in developing countries", Sustainability, Vol. 11 No. 2, p. 361. 10.3390/su11020361
Dushenko, M., Thærie Bjorbæk, C. and Steger-Jensen, K. (2018), "Application of a sustainability model for assessing the relocation of a container terminal: a case study of Kristiansand Port", Sustainability, Vol. 11 No. 1, 87. 87-18. 10.3390/su11010087

Elkington, J. (1994), "Towards the sustainable Corporation: Win-win-win business strategies for sustainable development", California Management Review, Vol. 36 No. 2, pp. 90-100. 10.2307/41165746

Elkington, J. (2013), "Enter the triple bottom line". The triple bottom line. London, UK: Routledge. pp. 23-38.

Elkington, J. (2018), 25 Years Ago, I Coined the Phrase "Triple Bottom Line." Here's Why It's Time to Rethink It, Harvard Business Review. 25 June 2018.

Emas, R. (2015), "The concept of sustainable development: definition and defining principles", Brief for GSDR, Vol. 2015. 10.13140/RG.2.2.34980.22404

Engert, S., Rauter, R. and Baumgartner, R.J. (2016), "Exploring the integration of corporate sustainability into strategic management: a literature review", Journal of Cleaner Production, Vol. 112 No. 4, pp. 2833-2850. 10.1016/j.jclepro.2015.08.031

Executive Office of the President, Office of Science and Technology Policy. (1989), The Federal HighPerformance Computing Program. pp. 49-50.

Farinosi, F., Giupponi, C., Reynaud, A., Ceccherini, G., Carmona-Moreno, C., De Roo, A., GonzalezSanchez, D. and Bidoglio, G. (2018), "An innovative approach to the assessment of hydro-political risk: a spatially explicit, data driven indicator of hydro-political issues", Global Environmental Change, Vol. 52, pp. 286-313. 10.1016/j.gloenvcha.2018.07.001

Fenner, R.A., Ainger, C.M., Cruickshank, H.J. and Guthrie, P.M. (2006), "Widening engineering horizons: addressing the complexity of sustainable development"ed. Proceedings of the Institution of Civil Engineers-Engineering Sustainability. vol. 159. London, UK: Thomas Telford Ltd. pp. 145154, (12). 10.1680/ensu.2006.159.4.145

Fuldauer, L.I., Ives, M.C., Adshead, D., Thacker, S. and Hall, J.W. (2019), "Participatory planning of the future of waste management in small island developing states to deliver on the sustainable development goals", Journal of Cleaner Production, Vol. 223, pp. 147-162. 10.1016/j.jclepro.2019.02.269

Glavič, P. and Lukman, R. (2007), "Review of sustainability terms and their definitions", Journal of Cleaner Production, Vol. 15 No. 18, pp. 1875-1885. 10.1016/j.jclepro.2006.12.006

Engineering Project Organization Journal

(C) 2021 Engineering Project Organization Society www.epossociety.org 
Global Infrastructure Outlook. (2019), “Infrastructure Investment need in the Compact with African countries", available at: https://outlook.gihub.org/? utm_source=GIHub+Homepage\&utm_medium= Project + tile\&utm_campaign $=$ Outlook + GIHub + Tile [accessed 23 Jul 2019].

Goel, A., Ganesh, L.S. and Kaur, A. (2019), "Sustainability integration in the management of construction projects: A morphological analysis of over two decades' research literature", Journal of Cleaner Production, Vol. 236 No. 2, 117676. 10.1016/j. jclepro.2019.117676

Griggs, D., Stafford-Smith, M., Gaffney, O., Rockström, J., Öhman, M.C., Shyamsundar, P., Steffen, W., Glaser, G., Kanie, N. and Noble, I. (2013), "Policy: sustainable development goals for people and planet", Nature, Vol. 495 No. 7441, 305. 10.1038/495305a

Hall, R., Ranganathan, S. and G. C., R. (2017), “A general Micro-Level modeling approach to analyzing interconnected SDGs: achieving SDG 6 and more through Multiple-Use water services (Mus)", Sustainability, Vol. 9 No. 2, p. 314. 10.3390/su9020314

Hartshorn, J., Maher, M., Crooks, J., Stahl, R. and Bond, Z. (2005), "Creative destruction: building toward sustainability", Canadian Journal of Civil Engineering, Vol. 32 No. 1, pp. 170-180. 10.1139/ 104-119

Head, B.W. and Alford, J. (2015), "Wicked problems: implications for public policy and management", Administration \& Society, Vol. 47 No. 6, pp. 711-739.

Heravi, G., Fathi, M. and Faeghi, S. (2017), "Multicriteria group decision-making method for optimal selection of sustainable industrial building options focused on petrochemical projects", Journal of Cleaner Production, Vol. 142 No. 2, pp. 2999-3013. 10.1016/j.jclepro.2016.10.168

Holling, C.S. (2001), "Understanding the complexity of economic, ecological, and social systems", Ecosystems, Vol. 4 No. 5, pp. 390-405. 10.1007/ s10021-001-0101-5

Jama, A.A. and Mourad, K.A. (2019), “Water services sustainability: institutional arrangements and shared responsibilities", Sustainability, Vol. 11 No. 3, p. 916. $10.3390 /$ su11030916

Jarvis, C. B., MacKenzie, S. B. and Podsakoff, P. M. (2003), "A critical review of construct indicators and measurement model misspecification in marketing and consumer research", Journal of Consumer Research, Vol. 30 No. 2, pp. 199-218. $10.1086 / 376806$
Jenner, S. (2016), Transforming government and public services: realising benefits through project portfolio management. Boca Raton, FL: CRC Press.

Kibert, C.J. (2013), Sustainable construction: Green building design and delivery. 3rd ed. Hoboken, NJ: Wiley.

Klaufus, C., van Lindert, P., van Noorloos, F. and Steel, G. (2017), “All-inclusiveness versus exclusion: urban project development in Latin America and Africa", Sustainability, Vol. 9 No. 11, p. 2038. 10.3390/su9112038

Lavagnon, A.I. (2009), "Project success as a topic in project management journals", Project Management Journal No., Vol. 40 No. 4. https://doi.org/10.1002/ pmj.20137

Liberati, A., Altman, D.G., Tetzlaff, J., Mulrow, C., Gøtzsche, P.C., Ioannidis, J.P. and Moher, D. (2009), "The PRISMA statement for reporting systematic reviews and meta-analyses of studies that evaluate health care interventions: explanation and elaboration", Annals of Internal Medicine, Vol. 151 No. 4, W-65. 10.7326/0003-4819-151-4-200908180-00136

Lucas, P.L., Hilderink, H.B.M., Janssen, P.H.M., KC, S., van Vuuren, D.P. and Niessen, L. (2019), "Future impacts of environmental factors on achieving the SDG target on child mortality-A synergistic assessment", Global Environmental Change, Vol. 57 No. 9890, p. 101925. 10.1016/j.gloenvcha.2019.05.009

Makino, T., Noda, K., Keokhamphui, K., Hamada, H., Oki, K. and Oki, T. (2016), "The effects of five forms of capital on thought processes underlying water consumption behavior in suburban Vientiane", Sustainability, Vol. 8 No. 6, p. 538. 10.3390/ su8060538

Martens, M.L. and Carvalho, M.M. (2016b), "Sustainability and success variables in the project management context: an expert panel", Project Management Journal, Vol. 47 No. 6, pp. 24-43. 10.1177/875697281604700603

Martens, M.L. and Carvalho, M.M. (2017), "Key factors of sustainability in project management context: A survey exploring the project managers' perspective", International Journal of Project Management, Vol. 35 No. Issue 6, pp. 1084-1102. 10.1016/j. ijproman.2016.04.004

Mebratu, D. (1998), "Sustainability and sustainable development: historical and conceptual review", Environmental impact assessment review No. , Vol. 18 No. 6, pp. 493-520. https://doi.org/10.1016/S01959255(98)00019-5

Menhas, R., Mahmood, S., Tanchangya, P., Safdar, M.N. and Hussain, S. (2019), "Sustainable Develop-

Engineering Project Organization Journal

(C) 2021 Engineering Project Organization Society www.epossociety.org 
ment under Belt and Road Initiative: A Case Study of China-Pakistan Economic Corridor's SocioEconomic Impact on Pakistan", Sustainability, Vol. 11 No. 21, p. 6143. 10.3390/su11216143

Mertz, D.R. (2005), "Grand challenges: a strategic plan for bridge engineering, NCHRP project 20-07/Task 199, transportation research board, Washington, DC".

Monteiro, N.B.R., Moita Neto, J.M. and da Silva, E.A. (2018), "Bibliometric study of the crushed stone mining sector", Mineral Processing and Extractive Metallurgy Review, Vol. 39 No. 4, pp. 235-249. 10.1080/08827508.2018.1433174

Moore, J.E., Mascarenhas, A., Bain, J. and Straus, S.E. (2017), "Developing a comprehensive definition of sustainability", Implementation science: IS, Vol. 12 No. 1, p. 110. 10.1186/s13012-017-0637-1

Morris, P. (2013), Reconstructing Programme Management. Chichester, UK: John Wiley \& Sons.

Morris, P. (2017), "Climate Change and what the project management profession should be doing about it. Association for Project Management", available at: https://www.apm.org.uk/media/7496/climatechange-report.pdf [accessed 11 May 2018].

Müller, R., Drouin, N. and Sankaran, S. (2019), "Modeling organizational project management", Project Management Journal, Vol. 50 No. 4, pp. 499-513. 10.1177/8756972819847876

Munyasya, B. and Chileshe, N. (2018), "Towards sustainable infrastructure development: drivers, barriers, strategies, and coping mechanisms", Sustainability, Vol. 10 No. 12, p. 4341. 10.3390/ su10124341

Omenn, G.S. (2006), "Presidential address: grand challenges and great opportunities in science, technology, and public policy", Science, Vol. 314 No. 5806, pp. 1696-1704. 10.1126/science.1135003

Organisation for Economic Co-Operation and Development (OECD). (2019), "Measuring Distance to the SDG Targets 2019: An Assessment of Where OECD Countries Stand", available at: https://read.oecd-ilibrary.org/development/measuring-distance-to-thesdg-targets-2019_a8caf3fa-en\#page1 [accessed 15 Jul 2019].

Rockström, J., Steffen, W., Noone, K., Persson, Å., Chapin, F.S., Lambin, E.F., Lenton, T.M., Scheffer, M., Folke, C., Schellnhuber, H.J., Nykvist, B., de Wit, C.A., Hughes, T., van der Leeuw, S., Rodhe, H., Sörlin, S., Snyder, P.K., Costanza, R., Svedin, U., Falkenmark, M., Karlberg, L., Corell, R.W., Fabry, V.J., Hansen, J., Walker, B., Liverman, D., Richardson, K., Crutzen, P. and Foley, J.A. (2009),
"A safe operating space for humanity", Nature, Vol. 461 No. 7263, pp. 472-475. 10.1038/461472a

Sachs, J., Schmidt-Traub, G., Kroll, C., DurandDelacre, D. and Teksoz, K. (2016), SDG index \& dashboards: A global report. Gütersloh, Germany: Bertelsmann Stiftung.

Sakhrani, V., Chinowsky, P, S. and Taylor, J. (2016), "Grand challenges in engineering project organization", The Engineering Project Organization Journal, Vol. 7, pp. 1-18. 10.25219/epoj.2017.00102

Schwanitz, V., Wierling, A. and Shah, P. (2017), “Assessing the impact of renewable energy on regional Sustainability - A comparative study of Sogn OG Fjordane (Norway) and Okinawa (Japan", Sustainability, Vol. 9 No. 11, p. 1969. 10.3390/su9111969

Seinfeld, J.H. and Pandis, S.N. (2016), Atmospheric chemistry and physics: from air pollution to climate change. Hoboken, New Jersey: John Wiley \& Sons.

Shen, L.-yin., Tam, V.W.Y., Tam, L. Ji, Y.-bo, Shen, L, Ji, Y. (2010), "Project feasibility study: the key to successful implementation of sustainable and socially responsible construction management practice", Journal of Cleaner Production, Vol. 18 No. 3, pp. 254-259. 10.1016/j.jclepro.2009.10.014

Silvius, G., Schipper, R., Planko, J., van der Brink, J. and Köhler, A. (2012), Sustainability in project management. Surrey: Gower Publishing Limited.

Sperling, J., Romero-Lankao, P. and Beig, G. (2016), "Exploring citizen infrastructure and environmental priorities in Mumbai, India", Environmental Science \& Policy, Vol. 60 No. 1, pp. 19-27. 10.1016/j.envsci.2016.02.006

Steffen, W., Richardson, K., Rockström, J., Cornell, S.E., Fetzer, I., Bennett, E.M., Biggs, R., Carpenter, S.R., de Vries, W., de Wit, C.A., Folke, C., Gerten, D., Heinke, J., Mace, G.M., Persson, L.M., Ramanathan, V., Sörlin, S. and Sörlin, S. (2015), "Sustainability. planetary boundaries: guiding human development on a changing planet", Science, Vol. 347 No. 6223, 1259855. 10.1126/science.1259855

Sverdrup, H. and Rosen, K. (1998), "Long-Term base cation mass balances for Swedish forests and the concept of sustainability", Forest Ecology and Management, Vol. 110 No. 1-3, pp. 221-236. 10.1016/ S0378-1127(98)00283-7

Teferi, Z.A. and Newman, P. (2018), "Slum upgrading: can the $1.5^{\circ} \mathrm{C}$ carbon reduction work with SDGs in these settlements?" Urban Planning, Vol. 3 No. 2 52-63. 10.17645/up.v3i2.1239

Terrapon-Pfaff, J., Ortiz, W., Dienst, C. and Gröne, M.C. (2018), "Energising the WEF nexus to enhance sustainable development at local level", Journal of 
environmental management, Vol. 223, pp. 409-416. 10.1016/j.jenvman.2018.06.037

Thacker, S., Adshead, D., Fay, M., Hallegatte, S., Harvey, M., Meller, H., O’Regan, N., Rozenberg, J., Watkins, G. and Hall, J.W. (2019), "Infrastructure for sustainable development", Nature Sustainability, Vol. 2 No. 4 324-331. 10.1038/s41893-019-0256-8

Thacker, S. and Hall, J. (2018), Engineering for Sustainable Development. Oxford, UK: Infrastructure Transition Research Consortium (ITRC), University of Oxford.

Thiry, M. (2004), "Value Management". In: Morris P, Pinto J, eds, Wiley Guide to Managing Projects. Holbroken, NJ: Wiley.

Torraco, R.J. (2005), "Writing integrative literature reviews: guidelines and examples", Human Resource Development Review, Vol. 4 No. 3, pp. 356-367. $10.1177 / 1534484305278283$

Tranfield, D., Denyer, D. and Smart, P. (2003), “Towards a methodology for developing evidenceinformed management knowledge by means of systematic review", British Journal of Management, Vol. 14 No. 3, pp. 207-222. 10.1111/14678551.00375

United Nations. (2015), Transforming Our World: The 2030 agenda for sustainable development, Resolution Adopted by the General Assembly. United Nations, New York: .

United Nations. (2018), "The Sustainable Development Goals Report 2018”, available at: https://unstats.un. org/sdgs/files/report/2018/TheSustainableDevelo pmentGoalsReport2018-EN.pdf [accessed 15 Jul 2019].

United Nations Intergovernmental Panel on Climate Change (IPCC). (2018), "Global warming of $1.5^{\circ} \mathrm{C}$, an IPCC special report on the impacts of global warming of $1.5^{\circ} \mathrm{C}$ above pre-industrial levels and related global greenhouse gas emission pathways, in the context of strengthening the global response to the threat of climate change, sustainable development, and efforts to eradicate poverty".

United Nations Intergovernmental Science-Policy Platform on Biodiversity and Ecosystem Services. (2019), "Report of the Plenary of the Intergovernmental Science-Policy Platform on Biodiversity and Ecosystem Services on the work of its seventh session", available at: https://www.ipbes.net/system/ tdf/ipbes_7_10_add-1-_advance_0.pdf?file=1\& type $=$ node $\&$ id $=35245$ [accessed 15 Jul 2019].

Wong, K.K.K. (2013), "Partial least squares structural equation modelling (PLS-SEM) techniques using SmartPLS", Marketing Bulletin, Vol. 24 No. 1, pp. $1-32$.

Zhang, Q., Liu, S., Wang, T., Dai, X., Baninla, Y., Nakatani, J. and Moriguchi, Y. (2019), "Urbanization impacts on greenhouse gas (GHG) emissions of the water infrastructure in China: trade-offs among sustainable development goals (SDGs", Journal of Cleaner Production, Vol. 232 No. 1, pp. 474-486. 10.1016/j.jclepro.2019.05.333

Zuofa, T. and Ochieng, E. (2016), "Sustainability in construction project delivery: a study of experienced project managers in Nigeria", Project Management Journal, Vol. 47 No. 6, pp. 44-55. 10.1177/875697281604700604

Økland, A. (2015), "Gap analysis for incorporating sustainability in project management", Procedia Computer Science, Vol. 64 No. 2, pp. 103-109. 10.1016/j.procs.2015.08.469
Engineering Project Organization Journal

(C) 2021 Engineering Project Organization Society www.epossociety.org 


\section{APPENDICES}

\section{Appendix 1 - Table of data across the seven SDG-IP Thematics}

The main data points from the SLR analysis have been collated into the table below that summarises the key thematics across the seven codified areas. This provides a high-level overview of the focus areas of the selected dataset.

\begin{tabular}{|c|c|c|c|c|c|c|c|c|c|}
\hline $\begin{array}{l}\text { Combined } \\
\text { search } \\
\text { keywords }\end{array}$ & Authors & Article title & $\begin{array}{l}\text { Type of } \\
\text { contribution }\end{array}$ & $\begin{array}{l}\text { Primary } \\
\text { research } \\
\text { design }\end{array}$ & $\begin{array}{l}\text { Primary } \\
\text { geographical } \\
\text { focus }\end{array}$ & $\begin{array}{l}\text { Infrastructure } \\
\text { sector focus }\end{array}$ & $\begin{array}{l}\text { Industry / } \\
\text { Narrowed } \\
\text { Sector }\end{array}$ & Level & $\begin{array}{l}\text { SDGs } \\
\text { mentioned }\end{array}$ \\
\hline $\begin{array}{l}\text { SDG \& } \\
\text { Project }\end{array}$ & $\begin{array}{l}\text { Hall et al. } \\
\text { (2017) }\end{array}$ & $\begin{array}{l}\text { A general micro-level modelling } \\
\text { approach to analysing interconnected } \\
\text { SDGs: Achieving SDG } 6 \text { and more } \\
\text { through multiple-use water services } \\
\text { (MUS) }\end{array}$ & $\begin{array}{l}\text { Framework } \\
\text { proposition }\end{array}$ & $\begin{array}{l}\text { Multiple } \\
\text { case study }\end{array}$ & Mozambique & Water & $\begin{array}{l}\text { Rural water } \\
\text { services }\end{array}$ & $\begin{array}{l}\text { Project; } \\
\text { Organisational }\end{array}$ & SDG 6 \\
\hline $\begin{array}{l}\text { SDG \& } \\
\text { Project }\end{array}$ & $\begin{array}{l}\text { Klaufus } \\
\text { et al. } \\
(2017)\end{array}$ & $\begin{array}{l}\text { All-inclusiveness versus exclusion: } \\
\text { Urban project development in Latin } \\
\text { America and Africa }\end{array}$ & $\begin{array}{l}\text { Framework } \\
\text { proposition }\end{array}$ & $\begin{array}{l}\text { Multiple } \\
\text { case study }\end{array}$ & $\begin{array}{l}\text { Latin } \\
\text { America \& } \\
\text { Africa }\end{array}$ & $\begin{array}{l}\text { Urban } \\
\text { development }\end{array}$ & N/A & Local; Sectoral & SDG 11 \\
\hline $\begin{array}{l}\text { SDG \& } \\
\text { Project }\end{array}$ & $\begin{array}{l}\text { Farinosi } \\
\text { et al. } \\
(2018)\end{array}$ & $\begin{array}{l}\text { An innovative approach to the } \\
\text { assessment of hydro-political risk: A } \\
\text { spatially explicit, data driven indicator } \\
\text { of hydro-political issues }\end{array}$ & $\begin{array}{l}\text { Framework } \\
\text { proposition }\end{array}$ & $\begin{array}{l}\text { Empirical } \\
\text { analysis }\end{array}$ & Global & Water & $\begin{array}{l}\text { Trans- } \\
\text { boundary } \\
\text { resources }\end{array}$ & Global & SDG 6.5 .2 \\
\hline $\begin{array}{l}\text { SDG \& } \\
\text { Project }\end{array}$ & $\begin{array}{l}\text { Dean et al. } \\
(2017)\end{array}$ & $\begin{array}{l}\text { Assessing the value of housing } \\
\text { schemes through sustainable return } \\
\text { on investment: A path towards } \\
\text { sustainability-led evaluations? }\end{array}$ & $\begin{array}{l}\text { Framework } \\
\text { testing }\end{array}$ & $\begin{array}{l}\text { Multiple } \\
\text { case study }\end{array}$ & $\begin{array}{l}\text { United } \\
\text { Kingdom }\end{array}$ & Housing & $\begin{array}{l}\text { Social } \\
\text { housing }\end{array}$ & Project & SDG 11 \\
\hline $\begin{array}{l}\text { SDG \& } \\
\text { Project }\end{array}$ & $\begin{array}{l}\text { Goel et al. } \\
\text { (2019) }\end{array}$ & $\begin{array}{l}\text { Deductive content analysis of research } \\
\text { on sustainable construction in India: } \\
\text { current progress and future directions }\end{array}$ & $\begin{array}{l}\text { Framework } \\
\text { proposition }\end{array}$ & $\begin{array}{l}\text { Systematic } \\
\text { literature } \\
\text { review }\end{array}$ & $\begin{array}{l}\text { India with } \\
\text { developing } \\
\text { economy } \\
\text { reach }\end{array}$ & Not specified & Construction & Industry & General \\
\hline $\begin{array}{l}\text { SDG \& } \\
\text { Project }\end{array}$ & $\begin{array}{l}\text { Heravi } \\
\text { et al. } \\
(2017)\end{array}$ & $\begin{array}{l}\text { Evaluation of sustainability indicators } \\
\text { of industrial buildings focused on } \\
\text { petrochemical projects }\end{array}$ & Theoretical & $\begin{array}{l}\text { Empirical } \\
\text { analysis }\end{array}$ & Iran & Buildings & $\begin{array}{l}\text { Industrial } \\
\text { (Petro- } \\
\text { chemical) }\end{array}$ & Industry & General \\
\hline $\begin{array}{l}\text { SDG \& } \\
\text { Project }\end{array}$ & $\begin{array}{l}\text { Ding et al. } \\
\text { (2019) }\end{array}$ & $\begin{array}{l}\text { From environmental soundness to } \\
\text { sustainable development: Improving } \\
\text { applicability of payment for ecosystem } \\
\text { services scheme for diverting regional } \\
\text { sustainability transition in developing } \\
\text { countries }\end{array}$ & $\begin{array}{l}\text { Framework } \\
\text { proposition }\end{array}$ & $\begin{array}{l}\text { Single case } \\
\text { study }\end{array}$ & China & Water & $\begin{array}{l}\text { Water } \\
\text { transfer }\end{array}$ & $\begin{array}{l}\text { Regional; } \\
\text { National }\end{array}$ & General \\
\hline $\begin{array}{l}\text { SDG \& } \\
\text { Project }\end{array}$ & $\begin{array}{l}\text { Lucas et al. } \\
(2019)\end{array}$ & $\begin{array}{l}\text { Future impacts of environmental } \\
\text { factors on achieving the SDG target } \\
\text { on child mortality-A synergistic } \\
\text { assessment }\end{array}$ & $\begin{array}{l}\text { Framework } \\
\text { testing }\end{array}$ & $\begin{array}{l}\text { Empirical } \\
\text { analysis }\end{array}$ & Global & $\begin{array}{l}\text { Health, Water, } \\
\text { Energy Nexus }\end{array}$ & N/A & Global & General \\
\hline $\begin{array}{l}\text { SDG \& } \\
\text { Project }\end{array}$ & $\begin{array}{l}\text { Ishikawa } \\
\text { Y., Murata } \\
\text { M., } \\
\text { Kawaguchi } \\
\text { T. }\end{array}$ & $\begin{array}{l}\text { Globally applicable water quality } \\
\text { simulation model for river basin } \\
\text { chemical risk assessment }\end{array}$ & $\begin{array}{l}\text { Framework } \\
\text { testing }\end{array}$ & $\begin{array}{l}\text { Single case } \\
\text { study }\end{array}$ & Japan & $\begin{array}{l}\text { Water \& } \\
\text { Sanitation }\end{array}$ & $\begin{array}{l}\text { River basins; } \\
\text { Water quality }\end{array}$ & Organisational & General \\
\hline $\begin{array}{l}\text { SDG \& } \\
\text { Project }\end{array}$ & $\begin{array}{l}\text { Wang W., } \\
\text { Chen J., } \\
\text { Liu Q., } \\
\text { Guo Z. }\end{array}$ & $\begin{array}{l}\text { Green project planning with realistic } \\
\text { multi-objective consideration in } \\
\text { developing sustainable port }\end{array}$ & $\begin{array}{l}\text { Framework } \\
\text { proposition }\end{array}$ & $\begin{array}{l}\text { Single case } \\
\text { study }\end{array}$ & China & Port & N/A & Sectoral & $\begin{array}{l}\text { General, } \\
\text { leaning } \\
\text { towards } \\
\text { environmental }\end{array}$ \\
\hline $\begin{array}{l}\text { SDG \& } \\
\text { Project }\end{array}$ & $\begin{array}{l}\text { Zhang L., } \\
\text { Chu Z., He } \\
\text { Q., Zhai P. }\end{array}$ & $\begin{array}{l}\text { Investigating the constraints to } \\
\text { building information modelling (BIM) } \\
\text { applications for sustainable building } \\
\text { projects: A case of China }\end{array}$ & Exploratory & $\begin{array}{l}\text { Empirical } \\
\text { analysis }\end{array}$ & China & Buildings & $\begin{array}{l}\text { Sustainable } \\
\text { buildings }\end{array}$ & Local; Sectoral & General \\
\hline $\begin{array}{l}\text { SDG \& } \\
\text { Project }\end{array}$ & $\begin{array}{l}\text { Calderón } \\
\text { Márquez } \\
\text { A.J., } \\
\text { Cassettari } \\
\text { Filho P.C., } \\
\text { Rutkowski } \\
\text { E.W., de } \\
\text { Lima Isaac } \\
\text { R. }\end{array}$ & $\begin{array}{l}\text { Landfill mining as a strategic } \\
\text { tool towards global sustainable } \\
\text { development }\end{array}$ & Exploratory & $\begin{array}{l}\text { Multiple } \\
\text { case study }\end{array}$ & $\begin{array}{l}\text { North } \\
\text { America, } \\
\text { Europe, } \\
\text { Asia and the } \\
\text { Middle East }\end{array}$ & $\begin{array}{l}\text { Waste } \\
\text { management }\end{array}$ & Solid Waste & $\begin{array}{l}\text { Regional; } \\
\text { Global }\end{array}$ & General \\
\hline $\begin{array}{l}\text { SDG \& } \\
\text { Project \& } \\
\text { Infrastructure }\end{array}$ & $\begin{array}{l}\text { Dushenko } \\
\text { et al. } \\
\text { (2018) }\end{array}$ & $\begin{array}{l}\text { Application of a sustainability model } \\
\text { for assessing the relocation of a } \\
\text { container terminal: A case study of } \\
\text { kristians and port }\end{array}$ & $\begin{array}{l}\text { Framework } \\
\text { testing }\end{array}$ & $\begin{array}{l}\text { Single case } \\
\text { study }\end{array}$ & Scandinavia & Port & N/A & Industry & General \\
\hline $\begin{array}{l}\text { SDG \& } \\
\text { Project \& } \\
\text { Infrastructure }\end{array}$ & $\begin{array}{l}\text { Terrapon- } \\
\text { Pfaff et al. } \\
\text { (2018) }\end{array}$ & $\begin{array}{l}\text { Energising the WEF nexus to enhance } \\
\text { sustainable development at local level }\end{array}$ & $\begin{array}{l}\text { Framework } \\
\text { testing }\end{array}$ & $\begin{array}{l}\text { Empirical } \\
\text { analysis }\end{array}$ & Global south & $\begin{array}{l}\text { Water, Energy, } \\
\text { Food Nexus }\end{array}$ & N/A & Project & General \\
\hline
\end{tabular}

Engineering Project Organization Journal

(C) 2021 Engineering Project Organization Society www.epossociety.org 


\begin{tabular}{|c|c|c|c|c|c|c|c|c|c|}
\hline $\begin{array}{l}\text { Combined } \\
\text { search } \\
\text { keywords }\end{array}$ & Authors & Article title & $\begin{array}{l}\text { Type of } \\
\text { contribution }\end{array}$ & $\begin{array}{l}\text { Primary } \\
\text { research } \\
\text { design }\end{array}$ & $\begin{array}{l}\text { Primary } \\
\text { geographical } \\
\text { focus }\end{array}$ & $\begin{array}{l}\text { Infrastructure } \\
\text { sector focus }\end{array}$ & $\begin{array}{l}\text { Industry / } \\
\text { Narrowed } \\
\text { Sector }\end{array}$ & Level & $\begin{array}{l}\text { SDGs } \\
\text { mentioned }\end{array}$ \\
\hline $\begin{array}{l}\text { SDG \& } \\
\text { Project \& } \\
\text { Infrastructure }\end{array}$ & $\begin{array}{l}\text { Menhas } \\
\text { et al. } \\
\text { (2019) }\end{array}$ & $\begin{array}{l}\text { Sustainable development under Belt } \\
\text { and Road Initiative: A case study of } \\
\text { China-Pakistan Economic Corridor's } \\
\text { socio-economic impact on Pakistan }\end{array}$ & Theoretical & $\begin{array}{l}\text { Single case } \\
\text { study }\end{array}$ & Pakistan & Multi-sector & N/A & Regional & General \\
\hline $\begin{array}{l}\text { SDG \& } \\
\text { Project \& } \\
\text { Infrastructure }\end{array}$ & $\begin{array}{l}\text { Anwar } \\
\text { et al. } \\
\text { (2017) }\end{array}$ & $\begin{array}{l}\text { Sustainable urbanisation and } \\
\text { development goals strategy through } \\
\text { public-private partnerships in a South- } \\
\text { Asian metropolis }\end{array}$ & Theoretical & $\begin{array}{l}\text { Multiple } \\
\text { case study }\end{array}$ & South Asia & $\begin{array}{l}\text { Urban } \\
\text { development }\end{array}$ & $\begin{array}{l}\text { Mega-cities; } \\
\text { PPPs }\end{array}$ & Regional & SDG 11 \\
\hline $\begin{array}{l}\text { SDG \& } \\
\text { Infrastructure }\end{array}$ & $\begin{array}{l}\text { Schwanitz } \\
\text { et al. } \\
\text { (2017) }\end{array}$ & $\begin{array}{l}\text { Assessing the impact of renewable } \\
\text { energy on regional sustainability-A } \\
\text { comparative study of Sogn og } \\
\text { Fjordane (Norway) and Okinawa } \\
\text { (Japan) }\end{array}$ & $\begin{array}{l}\text { Framework } \\
\text { proposition }\end{array}$ & $\begin{array}{l}\text { Multiple } \\
\text { case study }\end{array}$ & $\begin{array}{l}\text { Norway; } \\
\text { Japan }\end{array}$ & Energy & $\begin{array}{l}\text { Renewable } \\
\text { energy }\end{array}$ & Regional & General \\
\hline $\begin{array}{l}\text { SDG \& } \\
\text { Infrastructure }\end{array}$ & $\begin{array}{l}\text { Diaz- } \\
\text { Sarachaga } \\
\text { et al. } \\
(2016)\end{array}$ & $\begin{array}{l}\text { Evaluation of LEED for } \\
\text { neighbourhood development and } \\
\text { envision rating frameworks for their } \\
\text { implementation in poorer countries }\end{array}$ & $\begin{array}{l}\text { Framework } \\
\text { testing }\end{array}$ & $\begin{array}{l}\text { Multiple } \\
\text { case study }\end{array}$ & $\begin{array}{l}\text { Developing } \\
\text { countries }\end{array}$ & $\begin{array}{l}\text { Urban } \\
\text { development }\end{array}$ & N/A & Project & General \\
\hline $\begin{array}{l}\text { SDG \& } \\
\text { Infrastructure }\end{array}$ & $\begin{array}{l}\text { Sperling } \\
\text { et al. } \\
\text { (2016) }\end{array}$ & $\begin{array}{l}\text { Exploring citizen Infrastructure and } \\
\text { environmental priorities in Mumbai, } \\
\text { India }\end{array}$ & Theoretical & $\begin{array}{l}\text { Empirical } \\
\text { analysis }\end{array}$ & India & $\begin{array}{l}\text { Urban } \\
\text { development }\end{array}$ & N/A & Local & $\begin{array}{l}\text { General, } \\
\text { leaning } \\
\text { towards } \\
\text { SDG } 11\end{array}$ \\
\hline $\begin{array}{l}\text { SDG \& } \\
\text { Infrastructure }\end{array}$ & $\begin{array}{l}\text { Aust et al. } \\
(2020)\end{array}$ & $\begin{array}{l}\text { How does foreign direct investment } \\
\text { contribute to Sustainable Development } \\
\text { Goals? Evidence from African } \\
\text { countries }\end{array}$ & Theoretical & $\begin{array}{l}\text { Empirical } \\
\text { analysis }\end{array}$ & $\begin{array}{l}\text { Africa (44 } \\
\text { countries) }\end{array}$ & Multi-sector & N/A & $\begin{array}{l}\text { National; } \\
\text { Regional }\end{array}$ & $\begin{array}{l}\text { General, } \\
\text { leaning } \\
\text { towards } \\
\text { SDG } 13\end{array}$ \\
\hline $\begin{array}{l}\text { SDG \& } \\
\text { Infrastructure }\end{array}$ & $\begin{array}{l}\text { Wei X., Xu } \\
\text { H., Zhang } \\
\text { B., Li J. }\end{array}$ & $\begin{array}{l}\text { Infrastructure operation efficiency } \\
\text { and influential factors in developing } \\
\text { countries: Evidence from China }\end{array}$ & Exploratory & $\begin{array}{l}\text { Multiple } \\
\text { case study }\end{array}$ & China & Roads & $\begin{array}{l}\text { Expressways; } \\
\text { Toll road } \\
\text { operations }\end{array}$ & Industry & General \\
\hline $\begin{array}{l}\text { SDG \& } \\
\text { Infrastructure }\end{array}$ & $\begin{array}{l}\text { Fuldauer } \\
\text { et al. } \\
\text { (2019) }\end{array}$ & $\begin{array}{l}\text { Participatory planning of the future } \\
\text { of waste management in small island } \\
\text { developing states to deliver on the } \\
\text { Sustainable Development Goals }\end{array}$ & $\begin{array}{l}\text { Framework } \\
\text { proposition }\end{array}$ & $\begin{array}{l}\text { Single case } \\
\text { study }\end{array}$ & Curacao & $\begin{array}{l}\text { Waste } \\
\text { management }\end{array}$ & N/A & National & General \\
\hline $\begin{array}{l}\text { SDG \& } \\
\text { Infrastructure }\end{array}$ & $\begin{array}{l}\text { Zheng } \\
\text { B., Bedra } \\
\text { K.B. }\end{array}$ & $\begin{array}{l}\text { Recent sustainability performance in } \\
\text { China: Strength-weakness analysis } \\
\text { and ranking of provincial cities }\end{array}$ & $\begin{array}{l}\text { Framework } \\
\text { proposition }\end{array}$ & $\begin{array}{l}\text { Empirical } \\
\text { analysis }\end{array}$ & China & $\begin{array}{l}\text { Urban } \\
\text { development }\end{array}$ & N/A & Local & General \\
\hline $\begin{array}{l}\text { SDG \& } \\
\text { Infrastructure }\end{array}$ & $\begin{array}{l}\text { Di Vaio and } \\
\text { Varriale } \\
(2018)\end{array}$ & $\begin{array}{l}\text { SDGs and airport sustainable } \\
\text { performance: Evidence from Italy } \\
\text { on organisational, accounting and } \\
\text { reporting practices through financial } \\
\text { and non-financial disclosure }\end{array}$ & $\begin{array}{l}\text { Framework } \\
\text { testing }\end{array}$ & $\begin{array}{l}\text { Multiple } \\
\text { case study }\end{array}$ & Italy & Airports & N/A & $\begin{array}{l}\text { Organisational; } \\
\text { Industry }\end{array}$ & SDG 11,17 \\
\hline $\begin{array}{l}\text { SDG \& } \\
\text { Infrastructure }\end{array}$ & $\begin{array}{l}\text { Teferi and } \\
\text { Newman } \\
(2018)\end{array}$ & $\begin{array}{l}\text { Slum regeneration and sustainability: } \\
\text { Applying the Extended Metabolism } \\
\text { Model and the SDGs }\end{array}$ & $\begin{array}{l}\text { Framework } \\
\text { testing }\end{array}$ & $\begin{array}{l}\text { Single case } \\
\text { study }\end{array}$ & Ethiopia & $\begin{array}{l}\text { Urban } \\
\text { development }\end{array}$ & $\begin{array}{l}\text { Slums and } \\
\text { settlements }\end{array}$ & Local & SDG 1 \\
\hline $\begin{array}{l}\text { SDG \& } \\
\text { Infrastructure }\end{array}$ & $\begin{array}{l}\text { da Silva } \\
\text { et al. } \\
\text { (2019) }\end{array}$ & $\begin{array}{l}\text { Sustainability indicators for urban } \\
\text { solid waste management in large and } \\
\text { medium-sized worldwide cities }\end{array}$ & $\begin{array}{l}\text { Framework } \\
\text { testing }\end{array}$ & $\begin{array}{l}\text { Multiple } \\
\text { case study }\end{array}$ & Brazil & $\begin{array}{l}\text { Waste } \\
\text { management }\end{array}$ & Solid waste & Local & General \\
\hline $\begin{array}{l}\text { SDG \& } \\
\text { Infrastructure }\end{array}$ & $\begin{array}{l}\text { Monteiro } \\
\text { et al. } \\
(2018)\end{array}$ & $\begin{array}{l}\text { Sustainable development goals in } \\
\text { mining }\end{array}$ & Exploratory & $\begin{array}{l}\text { Multiple } \\
\text { case study }\end{array}$ & Brazil & Mining & N/A & Industry & $\begin{array}{l}\text { SDG } 1,2,5, \\
8,13\end{array}$ \\
\hline $\begin{array}{l}\text { SDG \& } \\
\text { Infrastructure }\end{array}$ & $\begin{array}{l}\text { Makino } \\
\text { et al. } \\
(2016)\end{array}$ & $\begin{array}{l}\text { The effects of five forms of capital on } \\
\text { thought processes underlying water } \\
\text { consumption behaviour in suburban } \\
\text { vientiane }\end{array}$ & $\begin{array}{l}\text { Framework } \\
\text { testing }\end{array}$ & $\begin{array}{l}\text { Empirical } \\
\text { analysis }\end{array}$ & $\begin{array}{l}\text { Vientiane, } \\
\text { Lao }\end{array}$ & Water & Water supply & Local & General \\
\hline $\begin{array}{l}\text { SDG \& } \\
\text { Infrastructure }\end{array}$ & $\begin{array}{l}\text { Cheng } \\
\text { et al. } \\
\text { (2018) }\end{array}$ & Toilet revolution in China & Exploratory & $\begin{array}{l}\text { Literature } \\
\text { review }\end{array}$ & China & Sanitation & N/A & National & $\begin{array}{l}\text { General, } \\
\text { leaning } \\
\text { towards } \\
\text { SDG } 6\end{array}$ \\
\hline $\begin{array}{l}\text { SDG \& } \\
\text { Infrastructure }\end{array}$ & $\begin{array}{l}\text { Munyasya } \\
\text { and } \\
\text { Chileshe } \\
(2018)\end{array}$ & $\begin{array}{l}\text { Towards Sustainable Infrastructure } \\
\text { Development: Drivers, barriers, } \\
\text { strategies, and coping mechanisms }\end{array}$ & Theoretical & $\begin{array}{l}\text { Empirical } \\
\text { analysis }\end{array}$ & Australia & Not specified & Construction & $\begin{array}{l}\text { Industry; } \\
\text { Sectoral }\end{array}$ & General \\
\hline $\begin{array}{l}\text { SDG \& } \\
\text { Infrastructure }\end{array}$ & $\begin{array}{l}\text { Zhang et al. } \\
\text { (2019) }\end{array}$ & $\begin{array}{l}\text { Urbanisation impacts on greenhouse } \\
\text { gas (GHG) emissions of the water } \\
\text { Infrastructure in China: Trade-offs } \\
\text { among sustainable development goals } \\
\text { (SDGs) }\end{array}$ & $\begin{array}{l}\text { Framework } \\
\text { testing }\end{array}$ & $\begin{array}{l}\text { Empirical } \\
\text { analysis }\end{array}$ & China & $\begin{array}{l}\text { Water, Energy } \\
\text { Nexus }\end{array}$ & N/A & $\begin{array}{l}\text { Local; } \\
\text { Regional }\end{array}$ & SDG $6,11,13$ \\
\hline $\begin{array}{l}\text { SDG \& } \\
\text { Infrastructure }\end{array}$ & $\begin{array}{l}\text { Jama and } \\
\text { Mourad } \\
(2019)\end{array}$ & $\begin{array}{l}\text { Water services sustainability: } \\
\text { Institutional arrangements and shared } \\
\text { responsibilities }\end{array}$ & Theoretical & $\begin{array}{l}\text { Empirical } \\
\text { analysis }\end{array}$ & Somalia & Water & Water supply & $\begin{array}{l}\text { Sectoral; } \\
\text { National }\end{array}$ & $\begin{array}{l}\text { SDG } 6.1 \text {, } \\
\text { emphasising } \\
\text { its link to } \\
\text { many others }\end{array}$ \\
\hline
\end{tabular}




\section{Appendix 2 - Summary of the Level two research Issues and sub-issues examined within the top 13 most relevant articles.}

The nodal structure shown at Figure 8 is expanded below in Table 7 .

\begin{tabular}{|c|c|c|c|}
\hline Authors & $\begin{array}{l}\text { SDG-IP } \\
\text { research } \\
\text { issue }\end{array}$ & Sub-Issue & $\begin{array}{l}\text { Research issues and thematics extracted from the selected most relevant (based on } \\
\text { keyword occurrence articles) }\end{array}$ \\
\hline \multirow[b]{3}{*}{$\begin{array}{l}\text { Hall et al. } \\
(2017)\end{array}$} & \multirow{3}{*}{$\begin{array}{l}\text { Cascading } \\
\text { from Global } \\
\text { to the local } \\
\text { level }\end{array}$} & $\begin{array}{l}\text { Policy to } \\
\text { Implementation }\end{array}$ & $\begin{array}{l}\text { - The challenge now facing development organisations and governments is how to } \\
\text { operationalize this interconnected set of goals and targets through effective projects and } \\
\text { programmes. }\end{array}$ \\
\hline & & \multirow{2}{*}{$\begin{array}{l}\text { Micro- } \\
\text { level OPM } \\
\text { modelling } \\
\text { approach }\end{array}$} & $\begin{array}{l}\text { - This paper presents a micro-level modelling approach that can quantitatively } \\
\text { assess the impacts associated with rural water interventions that are tailored to specific } \\
\text { communities. }\end{array}$ \\
\hline & & & $\begin{array}{l}\text { - The multilevel modelling framework provides a generalizable template that can be } \\
\text { used in multiple sectors }\end{array}$ \\
\hline \multirow[b]{3}{*}{$\begin{array}{l}\text { Dean } \\
\text { et al. } \\
(2017)\end{array}$} & \multirow[b]{3}{*}{$\begin{array}{l}\text { Definition } \\
\text { and } \\
\text { evaluation } \\
\text { of Project } \\
\text { Success }\end{array}$} & \multirow[b]{2}{*}{$\begin{array}{l}\text { Inclusion of } \\
\text { socio-economic } \\
\text { assessment }\end{array}$} & $\begin{array}{l}\text { - Current evaluative methods that support decision making on social housing inter- } \\
\text { ventions fail to capture all of the socio-environmental value contained in the UN SDG } 11 .\end{array}$ \\
\hline & & & $\begin{array}{l}\text { - The paper addresses the issue by demonstrating how Sustainable Return on } \\
\text { Investment can successfully describe and analyse a range of externalities related to the } \\
\text { sustainable value generated by social housing regeneration schemes. }\end{array}$ \\
\hline & & $\begin{array}{l}\text { Inclusion of } \\
\text { environmental } \\
\text { and socio- } \\
\text { economic } \\
\text { assessment }\end{array}$ & $\begin{array}{l}\text { - The findings show that, historically, the environmental and social value of regener- } \\
\text { ation schemes have been largely disregarded because of a gap in the evaluation methods, } \\
\text { and that there is room for significant improvement for future evaluation exercises. }\end{array}$ \\
\hline \multirow[b]{4}{*}{$\begin{array}{l}\text { Goel et al. } \\
(2019)\end{array}$} & \multirow[b]{4}{*}{$\begin{array}{l}\text { Sustainable } \\
\text { Construction }\end{array}$} & $\begin{array}{l}\text { Lack of } \\
\text { relevant } \\
\text { research for } \\
\text { project levels }\end{array}$ & $\begin{array}{l}\text { - There is lack of studies that synthesise and critically evaluate the available litera- } \\
\text { ture to provide an overview of the current state of sustainable construction (SC) research } \\
\text { in India and provide directions for future research }\end{array}$ \\
\hline & & $\begin{array}{l}\text { Lack of } \\
\text { relevant } \\
\text { research for } \\
\text { project levels }\end{array}$ & $\begin{array}{l}\text { - Current SC research endeavours are predominantly oriented towards the macro- } \\
\text { industry level, the environmental dimension and the internal stakeholders. }\end{array}$ \\
\hline & & $\begin{array}{l}\text { Outputs versus } \\
\text { outcomes } \\
\text { success }\end{array}$ & $\begin{array}{l}\text { - Additionally, more emphasis has been provided on the final project deliverable } \\
\text { compared to the project processes. }\end{array}$ \\
\hline & & $\begin{array}{l}\text { Research } \\
\text { approach }\end{array}$ & $\begin{array}{l}\text { Overall, this study makes three specific contributions [of which the first two are]: } i \text { ) } \\
\text { the current thrust areas of SC research in India have been identified while pointing out the } \\
\text { imbalance in this academic pursuit; ii) a deductive content analysis framework has been } \\
\text { developed that provides a generic template for conducting similar SLRs in the context of } \\
\text { other countries }\end{array}$ \\
\hline \multirow{2}{*}{$\begin{array}{l}\text { Zhang L., } \\
\text { Chu Z., } \\
\text { He Q., } \\
\text { Zhai P. }\end{array}$} & \multirow{2}{*}{$\begin{array}{l}\text { Application } \\
\text { of BIM } \\
\text { technology } \\
\text { for } \\
\text { sustainability }\end{array}$} & $\begin{array}{l}\text { Challenges } \\
\text { to delivery of } \\
\text { sustainability }\end{array}$ & $\begin{array}{l}\text { Conducted a questionnaire survey with } 389 \text { respondents to investigate the applica- } \\
\text { tions of BIM technology in sustainable building projects. The results showed that there } \\
\text { were four main constraining factors: "Public participation", "technology application", } \\
\text { "economic cost", and "application management" "public participation" was particularly } \\
\text { important. }\end{array}$ \\
\hline & & $\begin{array}{l}\text { Opportunities } \\
\text { for delivery of } \\
\text { sustainability }\end{array}$ & $\begin{array}{l}\text { - The study offers practical and managerial implications based on the findings for } \\
\text { local government and the private sector }\end{array}$ \\
\hline \multirow{2}{*}{$\begin{array}{l}\text { Dushenko } \\
\text { et al. } \\
(2018)\end{array}$} & \multirow{2}{*}{$\begin{array}{l}\text { Practical } \\
\text { application of } \\
\text { Theoretical } \\
\text { sustainability } \\
\text { models }\end{array}$} & \multirow{2}{*}{$\begin{array}{l}\text { Limitations } \\
\text { of theoretical } \\
\text { models }\end{array}$} & $\begin{array}{l}\text { - When documenting a sustainable design of port projects, decision-makers use theo- } \\
\text { retical sustainability models to conceptualise features of a sustainable society. However, a } \\
\text { major challenge for the decision-makers was that the sustainability assessment results did } \\
\text { not show, as expected, the same results as those of three existing theoretical sustainability } \\
\text { models. }\end{array}$ \\
\hline & & & $\begin{array}{l}\text { The benchmark results indicate a disparity between the importance of what sustain- } \\
\text { ability models describe and what is important in practice. }\end{array}$ \\
\hline
\end{tabular}




\begin{tabular}{|c|c|c|c|}
\hline Authors & $\begin{array}{l}\text { SDG-IP } \\
\text { research } \\
\text { issue }\end{array}$ & Sub-Issue & $\begin{array}{l}\text { Research issues and thematics extracted from the selected most relevant (based on } \\
\text { keyword occurrence articles) }\end{array}$ \\
\hline \multirow[b]{3}{*}{$\begin{array}{l}\text { Terrapon- } \\
\text { Pfaff et al. } \\
\text { (2018) }\end{array}$} & \multirow{3}{*}{$\begin{array}{l}\text { Cascading } \\
\text { from Global } \\
\text { to the local } \\
\text { level }\end{array}$} & $\begin{array}{l}\text { Policy to } \\
\text { Implementation }\end{array}$ & $\begin{array}{l}\text { - Until now, the focus of WEF [water-energy-food] nexus discussions and applica- } \\
\text { tions has mainly been on national or global levels, macro-level drivers, material flows and } \\
\text { large Infrastructure developments. This overlooks the fact that major nexus challenges are } \\
\text { faced at local level. }\end{array}$ \\
\hline & & $\begin{array}{l}\text { Micro- } \\
\text { level OPM } \\
\text { modelling } \\
\text { approach }\end{array}$ & $\begin{array}{l}\text { - The study identifies the complex links which exist between sustainable energy } \\
\text { projects and the food and water sectors and highlights that these needs are currently not } \\
\text { systematically integrated into project design or project evaluation. }\end{array}$ \\
\hline & & $\begin{array}{l}\text { Outputs versus } \\
\text { outcomes } \\
\text { success }\end{array}$ & $\begin{array}{l}\text { A more systematic approach, integrating the water and food pillars into energy } \\
\text { planning at local level in the global south, is recommended to avoid trade-offs and en- } \\
\text { hance the development outcomes and impacts of energy projects. }\end{array}$ \\
\hline \multirow{3}{*}{$\begin{array}{l}\text { Schwanitz } \\
\text { et al. } \\
(2017)\end{array}$} & \multirow{3}{*}{$\begin{array}{l}\text { Definition } \\
\text { and } \\
\text { evaluation } \\
\text { of Project } \\
\text { Success }\end{array}$} & $\begin{array}{l}\text { Policy to } \\
\text { Implementation }\end{array}$ & $\begin{array}{l}\text { - Apply a range of assessment methods and study their usefulness as tools to identify } \\
\text { trade-offs and to compare the sustainability performance. We calculate cross-sectoral } \\
\text { footprints, self-sufficiency ratios and perform a simplified Energy-Water-Food nexus } \\
\text { analysis. }\end{array}$ \\
\hline & & $\begin{array}{l}\text { Outputs versus } \\
\text { outcomes } \\
\text { success }\end{array}$ & $\begin{array}{l}\text { - We recommend a general upgrade to indicators and visualisation methods that look } \\
\text { beyond averages and a fostering of infrastructure for data on sustainable development } \\
\text { based on harmonised international protocols. }\end{array}$ \\
\hline & & $\begin{array}{l}\text { Research } \\
\text { approach }\end{array}$ & $\begin{array}{l}\text { - We warn against rankings of countries or regions based on benchmarks that are } \\
\text { neither theory-driven nor location-specific. }\end{array}$ \\
\hline $\begin{array}{l}\text { Diaz- } \\
\text { Sarachaga } \\
\text { et al. } \\
(2016)\end{array}$ & $\begin{array}{l}\text { Definition } \\
\text { and } \\
\text { evaluation } \\
\text { of Project } \\
\text { Success }\end{array}$ & $\begin{array}{l}\text { Policy to } \\
\text { Implementation }\end{array}$ & $\begin{array}{l}\text { - Green rating systems have been launched during the last decades to facilitate the } \\
\text { assessment of sustainable development in terms of building and infrastructure, including } \\
\text { the evaluation of sustainable urban development through the study of communities. The } \\
\text { absence of metrics in the New Urban Agenda led to relate its commitments to the SDGs, } \\
\text { which revealed that the prerequisites and credits included in LEED ND and Envision } \\
\text { mainly focused on managerial and environmental aspects and disregarded the economic } \\
\text { and social dimensions. Consequently, the premises under which LEED ND and Envision } \\
\text { were developed must be updated and complemented with the two latest guidelines recently } \\
\text { adopted by the United Nations in the field of urban and sustainable development. }\end{array}$ \\
\hline \multirow[b]{2}{*}{$\begin{array}{l}\text { Sperling } \\
\text { et al. } \\
(2016)\end{array}$} & \multirow[b]{2}{*}{$\begin{array}{l}\text { Cascading } \\
\text { from Global } \\
\text { to the local } \\
\text { level }\end{array}$} & $\begin{array}{l}\text { Policy to } \\
\text { Implementation }\end{array}$ & $\begin{array}{l}\text { - With growing discussion and tensions surrounding the new urban sustainable devel- } \\
\text { opment goal, announced by the UN in late September 2015, and a new global urban agen- } \\
\text { da document to be agreed upon at 'Habitat III', issues on whether sustainable urbanisation } \\
\text { priorities should be set at the international, national or local level remain controversial. }\end{array}$ \\
\hline & & $\begin{array}{l}\text { Micro- } \\
\text { level OPM } \\
\text { modelling } \\
\text { approach }\end{array}$ & $\begin{array}{l}\text { - As such, this study aims to first understand determinants of and variations in local } \\
\text { priorities across one city, with implications discussed for local-to-global urban sustain- } \\
\text { ability. }\end{array}$ \\
\hline \multirow[b]{5}{*}{$\begin{array}{l}\text { Aust et al. } \\
(2020)\end{array}$} & \multirow{5}{*}{$\begin{array}{l}\text { Investment } \\
\text { priorities in } \\
\text { SDG }\end{array}$} & $\begin{array}{l}\text { Policy to } \\
\text { Implementation }\end{array}$ & $\begin{array}{l}\text { The public and the private sectors play fundamental roles in mobilising capital to } \\
\text { achieve the } 2030 \text { Agenda of Sustainable Development. In particular, developing countries } \\
\text { can benefit from foreign direct investment (FDI) as a source of external financing in the } \\
\text { private sector. This study aims to investigate whether FDI contributes to the achievement } \\
\text { of Sustainable Development Goals (SDGs) in Africa. We analyse a sample of } 44 \text { African } \\
\text { countries regarding their SDG scores and apply a multivariate analysis and an ordered } \\
\text { profit model. }\end{array}$ \\
\hline & & $\begin{array}{l}\text { Opportunities } \\
\text { for delivery of } \\
\text { sustainability }\end{array}$ & $\begin{array}{l}\text { - Our results indicate that the presence of foreign investors positively influences SDG } \\
\text { scores. }\end{array}$ \\
\hline & & $\begin{array}{l}\text { Challenges } \\
\text { to delivery of } \\
\text { sustainability }\end{array}$ & $\begin{array}{l}\text { However, although FDI has a positive impact in areas such as basic infrastructure, } \\
\text { clean water, sanitation, and renewable energy, some adverse environmental consequences } \\
\text { may occur for host countries. In fact, the relationship between FDI and the probability of } \\
\text { achieving SDG13 (Climate action) is negative. }\end{array}$ \\
\hline & & $\begin{array}{l}\text { Policy to } \\
\text { Implementation }\end{array}$ & $\begin{array}{l}\text { - This study contributes to the literature on sustainable development and can be } \\
\text { useful for decision-makers in developing investment plans to support the achievement of } \\
\text { SDGs. }\end{array}$ \\
\hline & & $\begin{array}{l}\text { Policy to } \\
\text { Implementation }\end{array}$ & $\begin{array}{l}\text { - Furthermore, we provide evidence of a positive influence of FDI on the SDGs, which } \\
\text { might encourage further investments in Africa. }\end{array}$ \\
\hline
\end{tabular}




\begin{tabular}{|c|c|c|c|}
\hline Authors & $\begin{array}{l}\text { SDG-IP } \\
\text { research } \\
\text { issue }\end{array}$ & Sub-Issue & $\begin{array}{l}\text { Research issues and thematics extracted from the selected most relevant (based on } \\
\text { keyword occurrence articles) }\end{array}$ \\
\hline \multirow[b]{3}{*}{$\begin{array}{l}\text { Di Vaio } \\
\text { and } \\
\text { Varriale } \\
(2018)\end{array}$} & \multirow[b]{3}{*}{$\begin{array}{l}\text { Investment } \\
\text { priorities in } \\
\text { SDG }\end{array}$} & $\begin{array}{l}\text { Policy to } \\
\text { Implementation }\end{array}$ & $\begin{array}{l}\text { This article investigates the } 17 \text { Sustainable Development Goals (SDGs) Agenda } \\
\text { introduced by the United Nations, } 2015 \text { in } 2015 \text { outlining if and which organisational, } \\
\text { accounting and reporting practices are adopted to sustainable performance. Specifically, } \\
\text { adopting the sustainability disclosure framework, we analyse how firms within the airport } \\
\text { industry achieve the SDGs } 11 \text { and } 17 \text { showing how the initiatives are developed and imple- } \\
\text { mented. }\end{array}$ \\
\hline & & $\begin{array}{l}\text { Research } \\
\text { approach }\end{array}$ & $\begin{array}{l}\text { The article conducts a qualitative study through the reading and processing of finan- } \\
\text { cial statements and non-financial reports (sustainability and social reporting) of seven } \\
\text { major strategic airport infrastructures in Italy to outline the initiatives implemented for } \\
\text { meeting the SDGs. }\end{array}$ \\
\hline & & $\begin{array}{l}\text { Opportunities } \\
\text { for delivery of } \\
\text { sustainability }\end{array}$ & $\begin{array}{l}\text { - This article outlines the need to create conditions for developing and better imple- } \\
\text { menting the accounting and reporting practices, like the SBSC (Sustainable Balanced } \\
\text { Scorecard), as well as adequate organisational architectures and educational training and } \\
\text { management programmes for achieving the SDGs goals within firms. }\end{array}$ \\
\hline \multirow[b]{3}{*}{$\begin{array}{l}\text { da Silva } \\
\text { et al. } \\
(2019)\end{array}$} & \multirow{3}{*}{$\begin{array}{l}\text { Definition } \\
\text { and } \\
\text { evaluation } \\
\text { of Project } \\
\text { Success }\end{array}$} & $\begin{array}{l}\text { Policy to } \\
\text { Implementation }\end{array}$ & $\begin{array}{l}\text { - This work aimed to select a relevant set of sustainability indicators to analyse mu- } \\
\text { nicipal solid waste management (MSWM) in large and medium-sized worldwide cities and } \\
\text { to apply these findings in three municipalities located in the state of Rio Grande do Sul, in } \\
\text { southern Brazil. }\end{array}$ \\
\hline & & $\begin{array}{l}\text { Policy to } \\
\text { Implementation }\end{array}$ & $\begin{array}{l}\text { - The result was the selection of a set of } 49 \text { indicators for application in a case study. } \\
\text { It was only possible to measure } 11 \text { indicators with the information publicly available for } \\
\text { the three Brazilian cities studied, demonstrating the fragility of information regarding } \\
\text { sustainability issues. }\end{array}$ \\
\hline & & $\begin{array}{l}\text { Challenges } \\
\text { to delivery of } \\
\text { sustainability }\end{array}$ & $\begin{array}{l}\text { - Also, data related to social issues and natural and energy resources were insufficient } \\
\text { for indicators to be measured. The analysis revealed difficulties regarding the availability } \\
\text { of information in databases... }\end{array}$ \\
\hline \multirow{2}{*}{$\begin{array}{l}\text { Munyasya } \\
\text { and } \\
\text { Chileshe } \\
(2018)\end{array}$} & \multirow[b]{2}{*}{$\begin{array}{l}\text { Drivers of } \\
\text { Sustainable } \\
\text { Infrastructure }\end{array}$} & $\begin{array}{l}\text { Opportunities } \\
\text { for delivery of } \\
\text { sustainability }\end{array}$ & $\begin{array}{l}\text { - While there is a plethora of studies around sustainable infrastructure, there are } \\
\text { limited studies undertaken on the influencing drivers and barriers particularly within the } \\
\text { South Australian construction industry. }\end{array}$ \\
\hline & & $\begin{array}{l}\text { Challenges } \\
\text { to delivery of } \\
\text { sustainability }\end{array}$ & $\begin{array}{l}\text { "Lack of steering mechanism", "multi-disciplinary nature of the word "sustainabili- } \\
\text { ty", and "lack of cooperation and networking" were the critical barriers. }\end{array}$ \\
\hline
\end{tabular}




\section{Appendix 3 - Full Table of SLR data (1651 artefacts) - (digital data vailable on re- quest)}
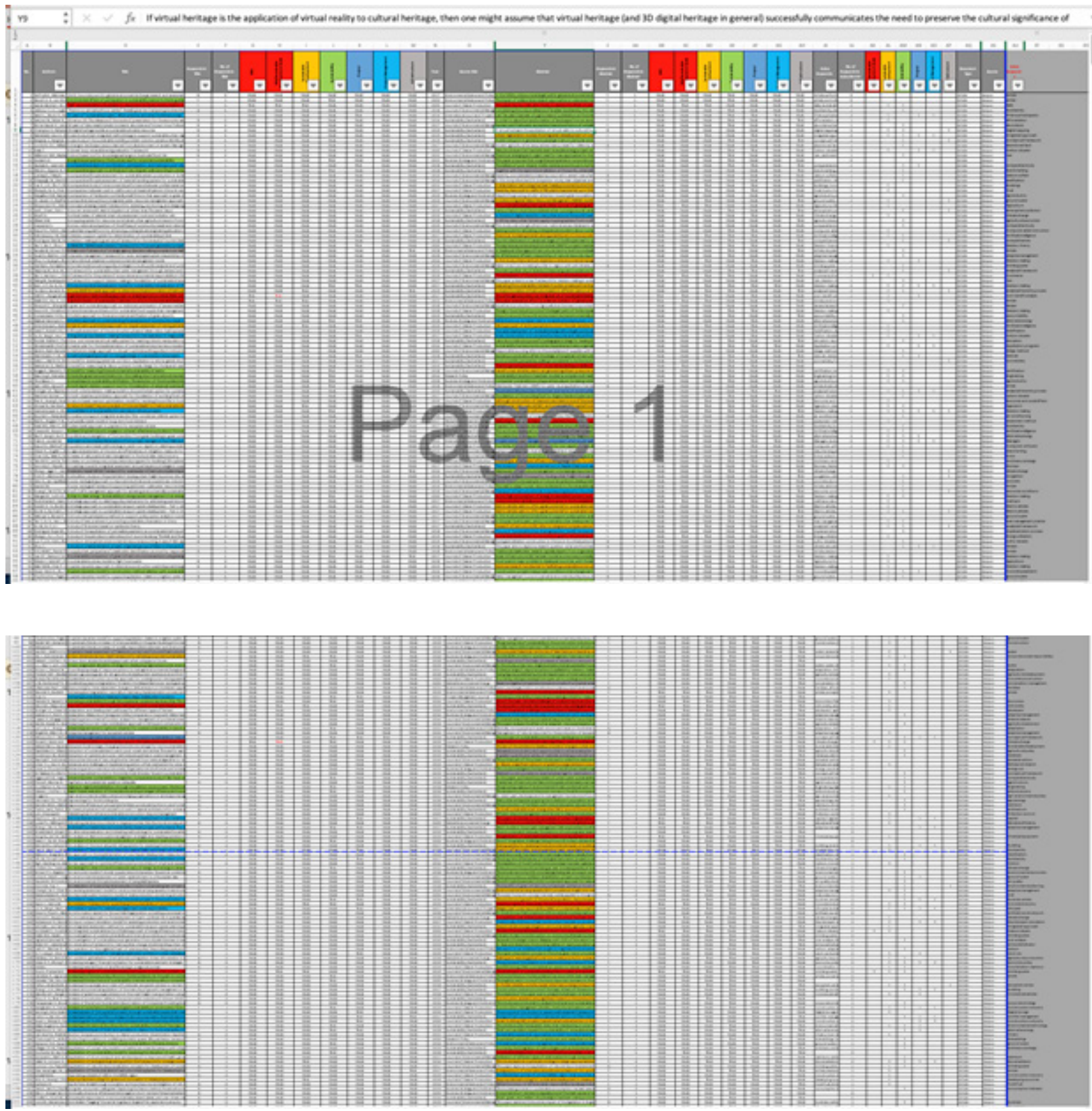

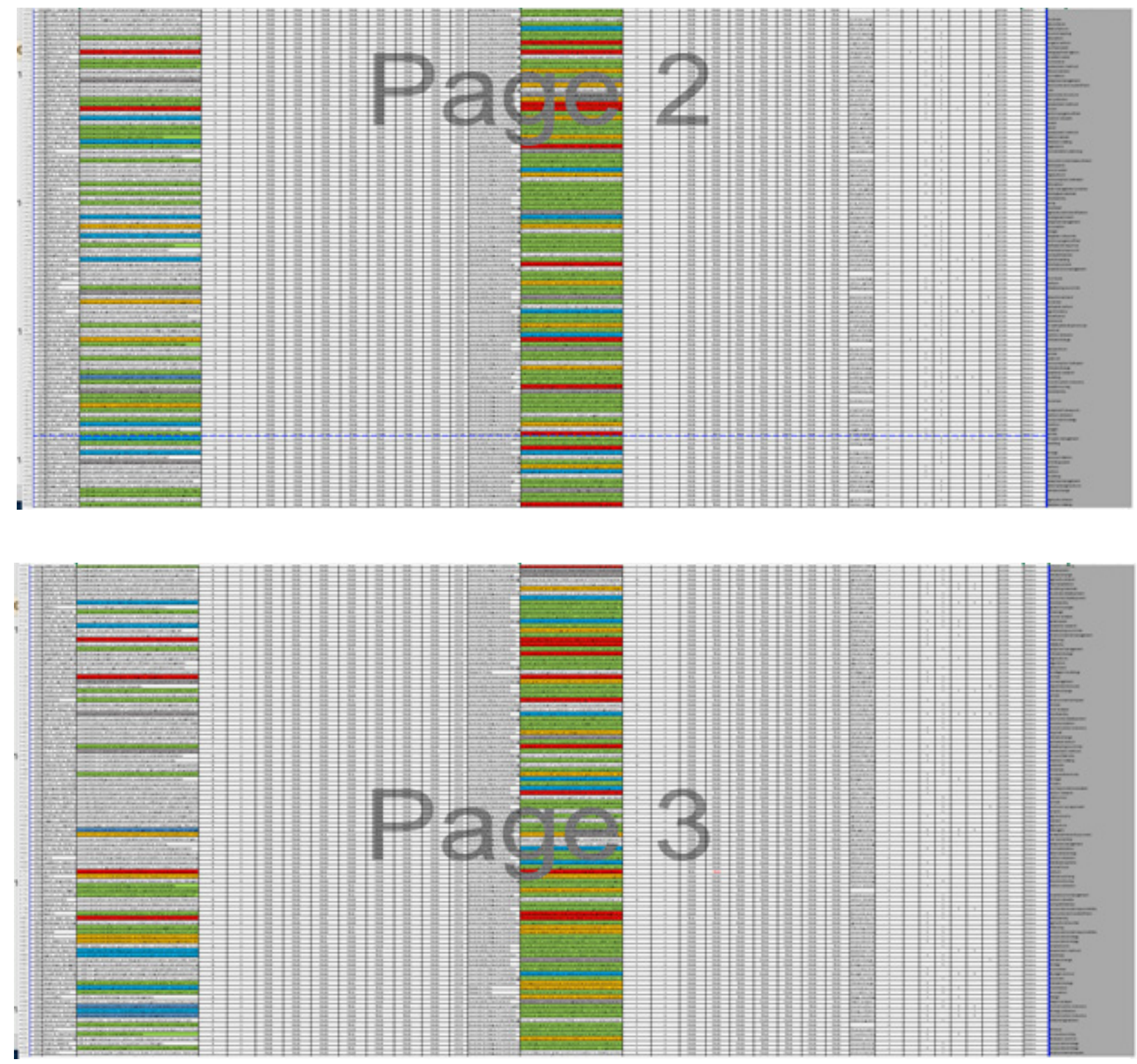

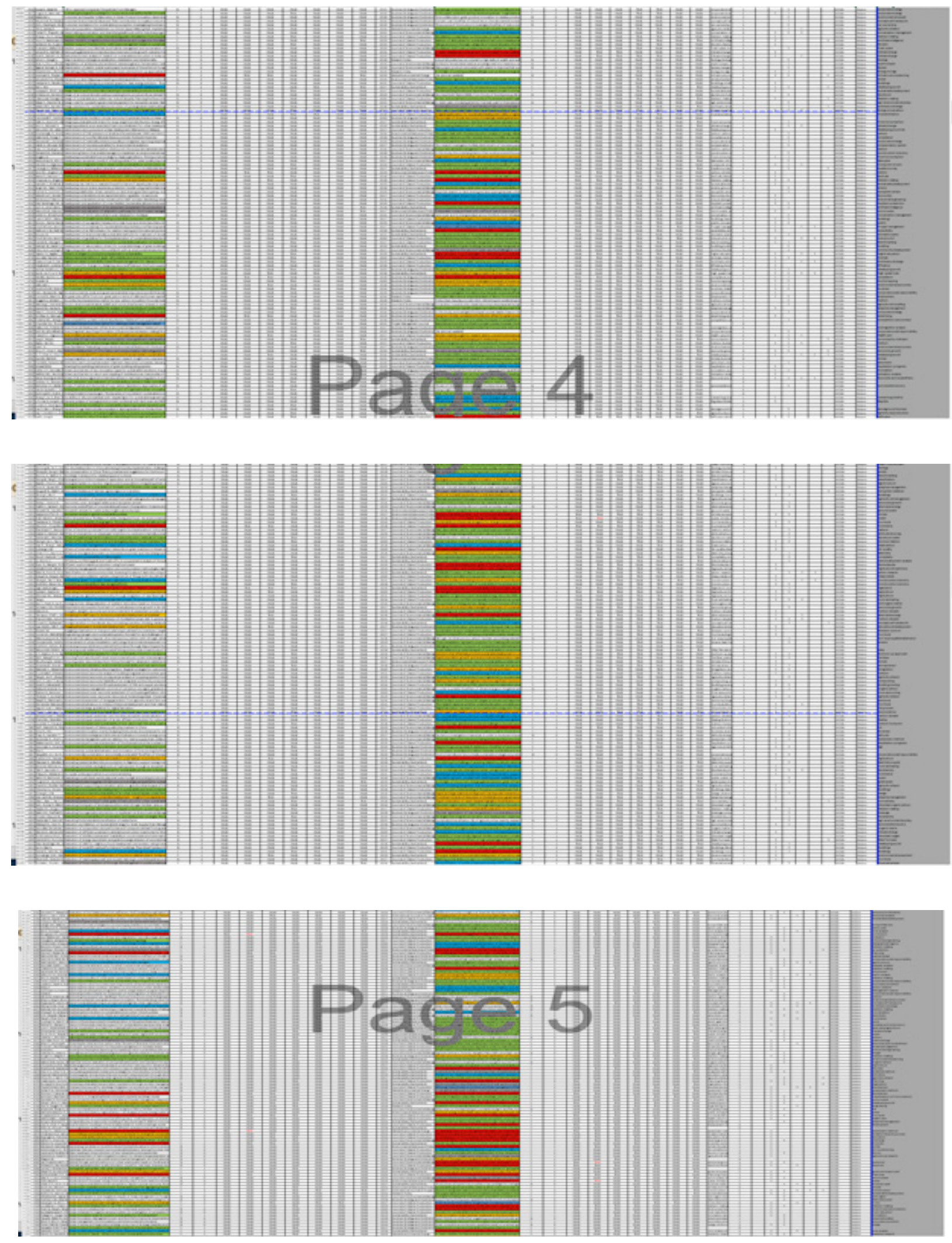

Engineering Project Organization Journal

(C) 2021 Engineering Project Organization Society

www.epossociety.org 

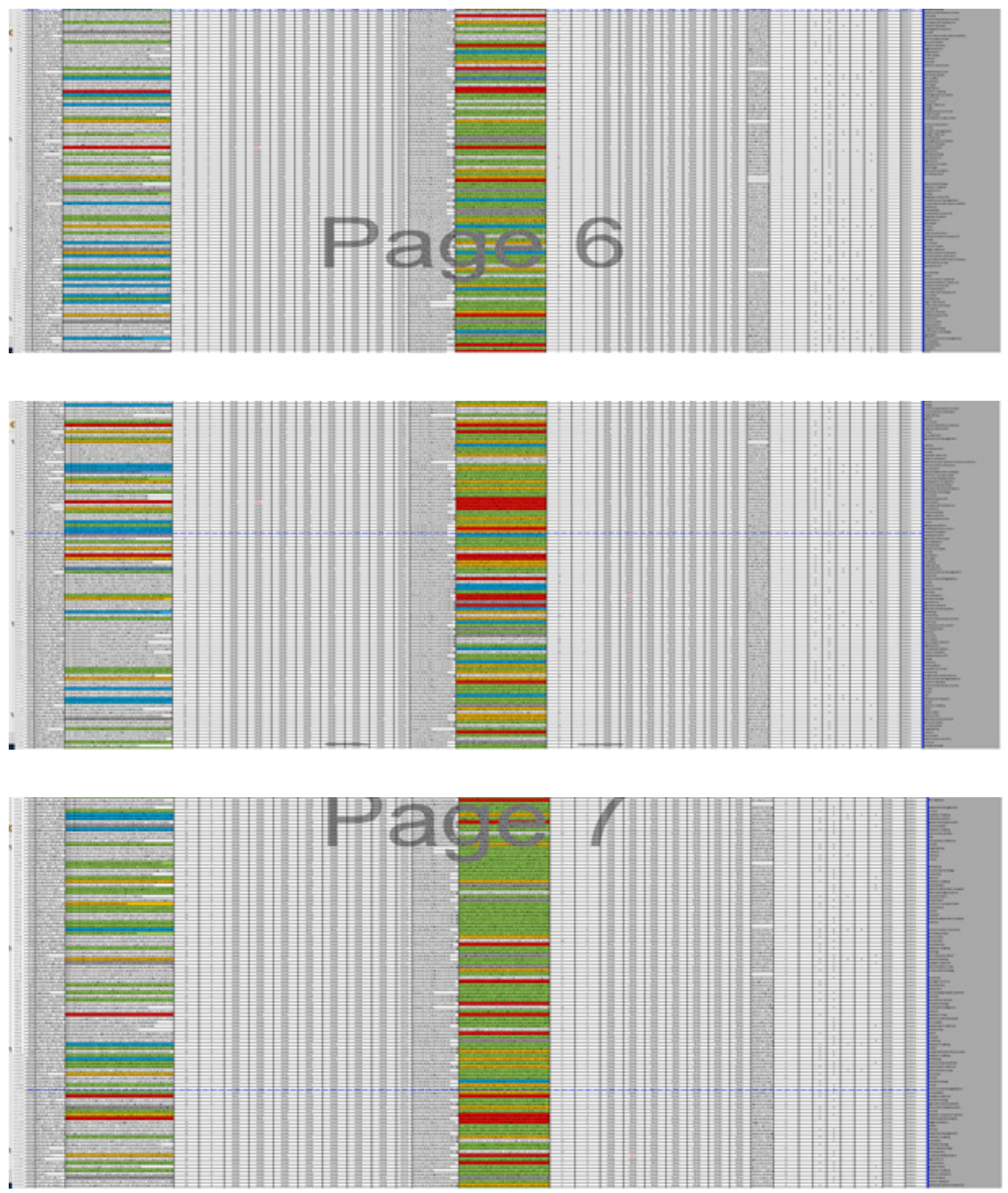

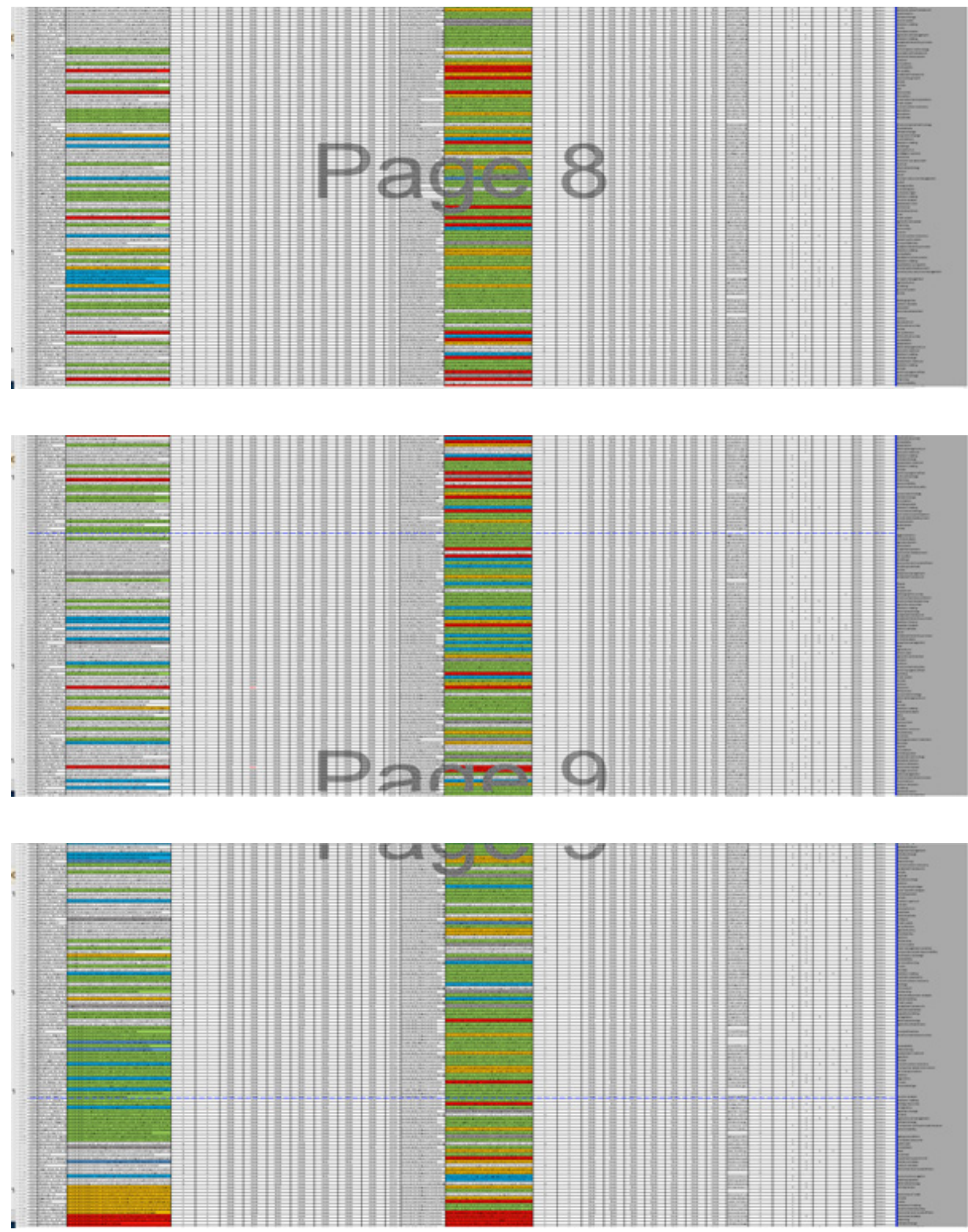

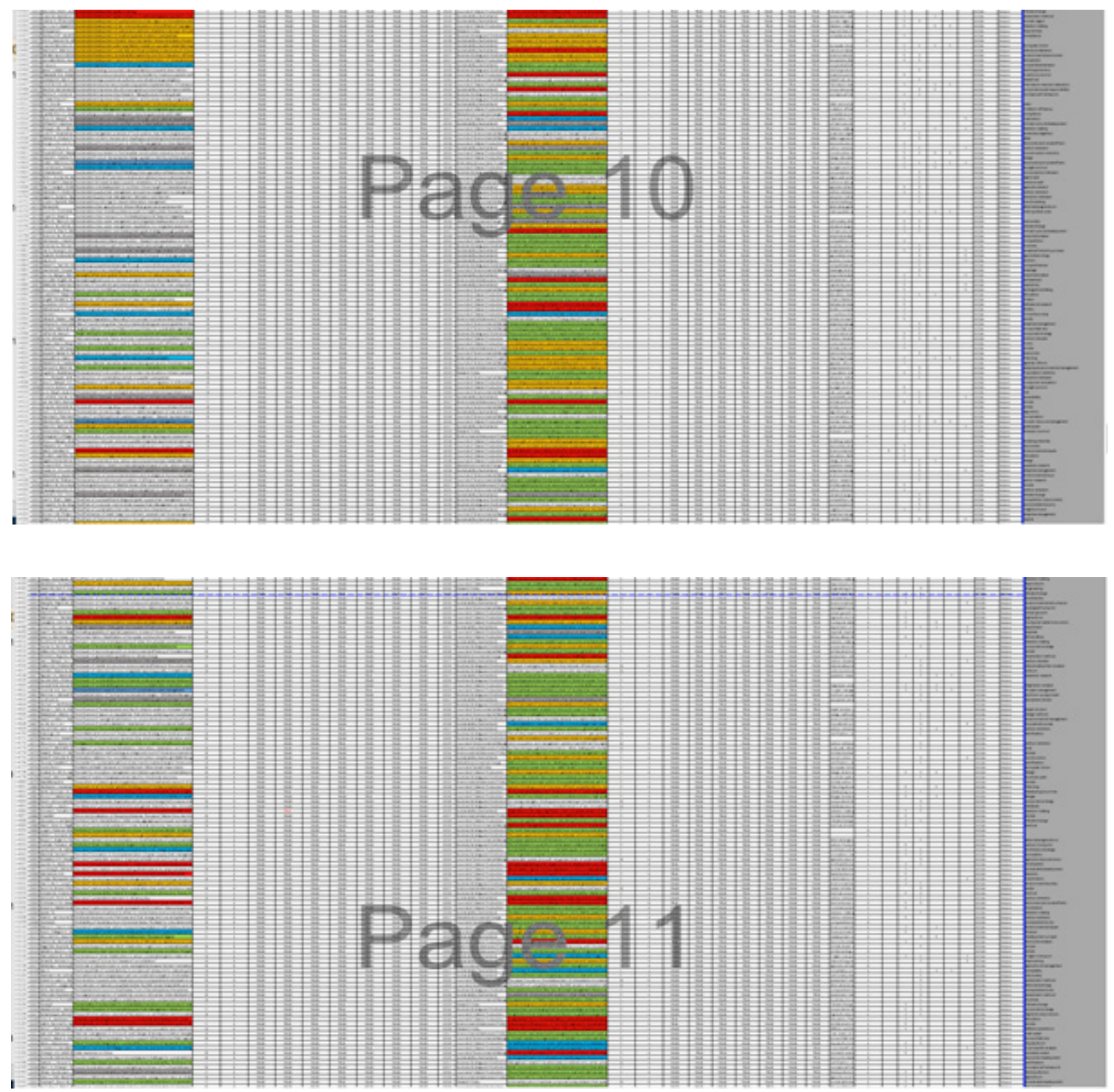
Engineering Project Organization Journal (May 2021) Volume 10

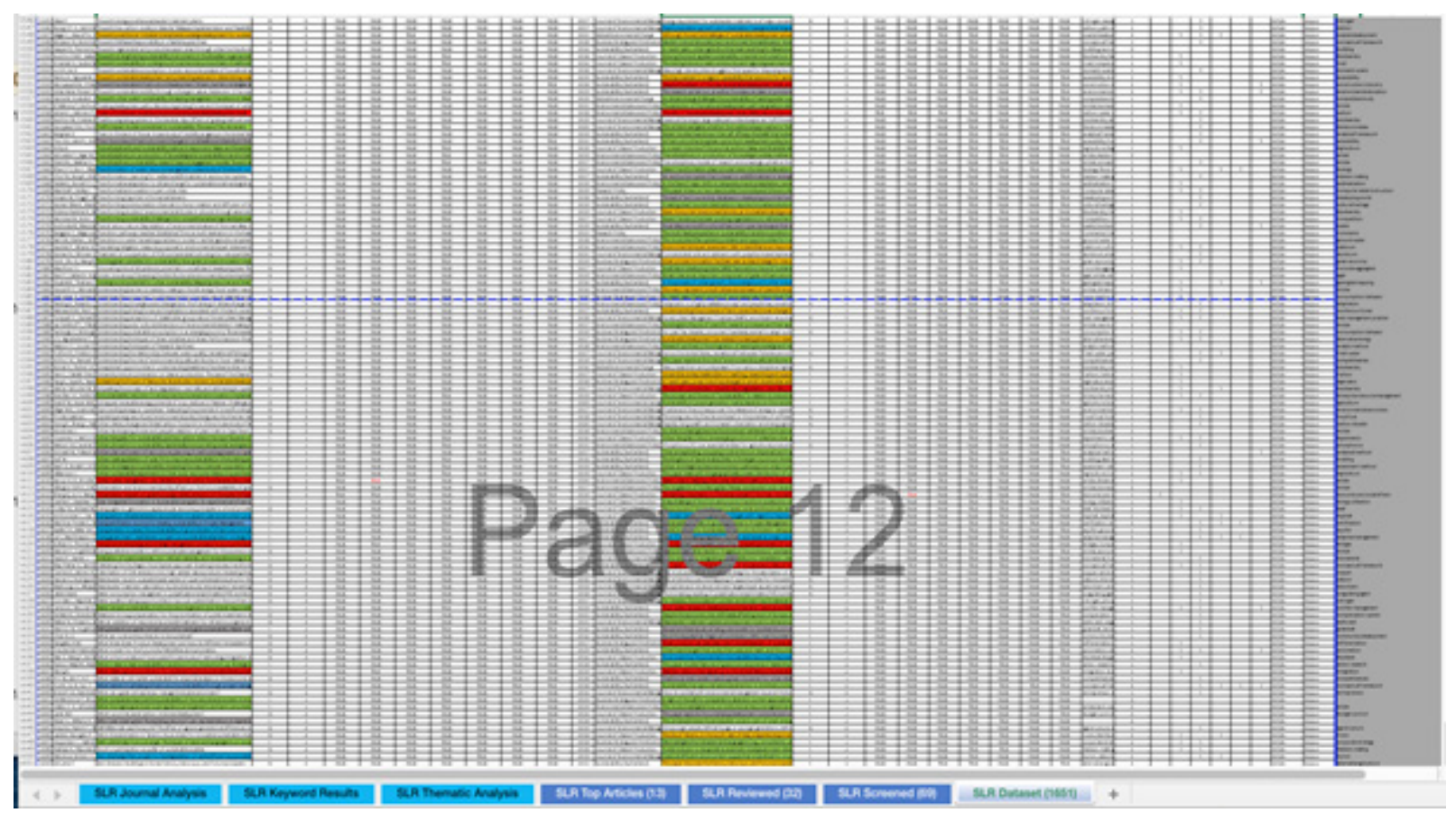

Engineering Project Organization Journal

(C) 2021 Engineering Project Organization Society

www.epossociety.org 